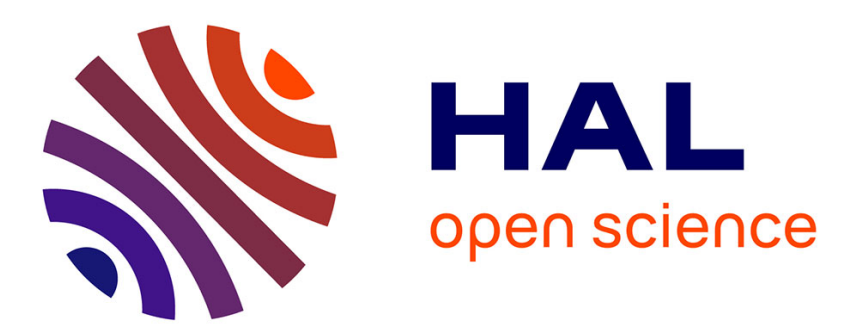

\title{
Origin of MORB enrichment and relative trace element compatibilities along the Mid-Atlantic Ridge between $10^{\circ}$ and $24^{\circ} \mathrm{N}$
}

Christophe C Hémond, Albrecht W. W. Hofmann, Ivan Vlastélic, François Nauret

\section{To cite this version:}

Christophe C Hémond, Albrecht W. W. Hofmann, Ivan Vlastélic, François Nauret. Origin of MORB enrichment and relative trace element compatibilities along the Mid-Atlantic Ridge between $10^{\circ}$ and $24^{\circ}$ N. Geochemistry, Geophysics, Geosystems, 2006, 7 n 12, pp.Q12010. 10.1029/2006GC001317 . hal-00128927

\section{HAL Id: hal-00128927 \\ https://hal.science/hal-00128927}

Submitted on 15 Feb 2011

HAL is a multi-disciplinary open access archive for the deposit and dissemination of scientific research documents, whether they are published or not. The documents may come from teaching and research institutions in France or abroad, or from public or private research centers.
L'archive ouverte pluridisciplinaire HAL, est destinée au dépôt et à la diffusion de documents scientifiques de niveau recherche, publiés ou non, émanant des établissements d'enseignement et de recherche français ou étrangers, des laboratoires publics ou privés. 
Click

Here

Full

Article

\title{
Origin of MORB enrichment and relative trace element compatibilities along the Mid-Atlantic Ridge between $10^{\circ}$ and $24^{\circ} \mathrm{N}$
}

\section{Christophe Hémond}

"Domaines Océaniques" I.U.E.M., Place Nicolas Copernic, F-29280 Plouzané France (chhemond@univ-brest.fr)

\author{
Albrecht W. Hofmann \\ Max-Planck-Institut für Chemie, Postfach 3060, D-55020 Mainz, Germany \\ Institut de Physique du Globe de Paris, 4 Place Jussieu, F-75230 Paris, France
}

Ivan Vlastélic

"Domaines Océaniques" I.U.E.M., Place Nicolas Copernic, F-29280 Plouzané France

Now at Laboratoire Magmas et Volcans, Université Blaise Pascal, 5 Rue Kessler, F-63038 Clermont-Ferrand Cedex, France

\author{
François Nauret \\ Max-Planck-Institut für Chemie, Postfach 3060, D-55020 Mainz, Germany \\ Now at Laboratoire de Géochimie et Cosmochimie, IPGP-CNRS UMR7154, 4 Place Jussieu, \\ F-75252 Paris Cedex 05, France
}

[1] The origin of chemically and isotopically enriched basalts along mid-ocean ridges (E-MORB) has been the subject of recent interest, particularly in cases where they are not related to a specific mantle plume. We present new isotope dilution analyses for $\mathrm{Th}, \mathrm{U}, \mathrm{La}, \mathrm{Ce}$, and $\mathrm{Pb}$ in 26 mostly glassy tholeiite samples dredged from the Mid-Atlantic Ridge (MAR) between $10^{\circ}$ and $24^{\circ} \mathrm{N}$. We interpret these data in combination with other previously published trace element data and isotope ratios for the same samples. We focus on the region at $14^{\circ}-15^{\circ} \mathrm{N}$, where incompatible trace element abundances are enriched by as much as factors of 40, relative to the depleted basalts found to the north and the south of this region. We invoke simple recycling of alkali basalts found on oceanic islands and seamounts as an alternative E-MORB origin to a recently published metasomatic enrichment model. A small amount of recycled alkali basalt is added to the local depleted mantle peridotite. Melting of such mixed sources can produce the observed E-MORB at $14^{\circ}-15^{\circ} \mathrm{N}$ MAR and elsewhere. The bulk partition coefficients of $\mathrm{Nb}, \mathrm{Ta}, \mathrm{K}$, and $\mathrm{Pb}$ (relative to other trace elements) are geochemically important because these elements are widely used as tracers of source chemistry. We evaluate their partitioning using simple log-log plots, and we compare the $10^{\circ}-24^{\circ}$ MAR basalts with a similar suite from the CIR $18^{\circ}-20^{\circ} \mathrm{S}$. In both suites, $\mathrm{Nb}$ (bulk) partitioning is close to $\mathrm{Th}$, and $\mathrm{Pb}$ is close to Pr. Tantalum partitioning is also very close to $\mathrm{Nb}$ in the MAR setting but between $\mathrm{U}$ and $\mathrm{K}$ in the CIR setting. Potassium is slightly more compatible than $\mathrm{U}$ in the MAR suite but less compatible in the CIR setting. Thus, although the bulk partition coefficients of these elements do vary slightly in different regions, their overall consistency is remarkable considering that the partitioning of the individual elements is governed by different mineral phases. 
Components: 11,666 words, 13 figures, 2 tables.

Keywords: MORB; trace elements; enrichment; compatibility; Mid-Atlantic Ridge; mantle isochron.

Index Terms: 1025 Geochemistry: Composition of the mantle; 1032 Geochemistry: Mid-oceanic ridge processes (3614, 8416); 1065 Geochemistry: Major and trace element geochemistry.

Received 28 March 2006; Revised 22 August 2006; Accepted 11 September 2006; Published 29 December 2006.

Hémond, C., A. W. Hofmann, I. Vlastélic, and F. Nauret (2006), Origin of MORB enrichment and relative trace element compatibilities along the Mid-Atlantic Ridge between $10^{\circ}$ and $24^{\circ} \mathrm{N}$, Geochem. Geophys. Geosyst., 7, Q12010, doi:10.1029/ 2006GC001317.

\section{Introduction}

[2] Mid-ocean ridge basalts (MORB) have long been classified into at least two different geochemical types, so-called "N-MORB" (normal) and "E-MORB" (enriched MORB) [e.g., Schilling, 1975; Sun et al., 1979]; note that in the early literature the enriched MORB were usually called "plume-ridge" or "P-MORB." In this nomenclature, "normal" actually refers to the very common, incompatible-element depleted variety, whereas "enriched" refers to the much less frequent, but nevertheless not uncommon, incompatibleelement enriched basalts. Modern MORB-data compilations clearly show that there is a complete continuum between depleted and enriched varieties [e.g., Hofmann, 2003]. Nevertheless, the N-MORB - E-MORB classification is still a convenient, though in many ways deficient and not quantitatively well-defined, characterization of ocean floor basalts.

[3] Many E-MORB (or "P-MORB") are clearly associated with obvious hot spots or plumes such as Iceland [Schilling, 1973]. Others have been interpreted to be formed by channels or offshoots of plume material into the asthenosphere [Schilling et al., 1985]. But some E-MORB, and this includes many small seamounts, cannot be attributed to input from any obvious plumes. Specific examples of the latter variety have recently been discussed by Donnelly et al. [2004] and by Nauret et al. [2006]. As is also the case for the more obvious "hot spots" or mantle plumes, the explanations for the cause of enrichment can be classified roughly into two categories, recycled oceanic crust (with or without minor amounts of continental input) [Hofmann and White, 1982], and recycled subcrustal, usually also oceanic, lithosphere that has been enriched "metasomatically," that is, by infiltration of low-degree melts at some point during its journey from the ridge through the subduction zone [Donnelly et al., 2004; Workman et al., 2004].

[4] In this paper, we report new trace element data for another, well-known region of E-MORB from the Mid-Atlantic Ridge in the vicinity of $14^{\circ}-$ $15^{\circ} \mathrm{N}$ (Figure 1). This region is far from any known mantle hot spot or plume, and although there are some nearby seamounts, there is at best a weakly developed depth anomaly associated with the geochemical enrichment. We compare the results with those previously obtained from the Central Indian Ridge and the MARK area in the Atlantic Ocean, and we show that the enrichments in all three areas are similar. We discuss possible origins for this enrichment, and we find that the metasomatic enrichment model of Donnelly et al. [2004] can also be applied to the results from $14^{\circ}-15^{\circ} \mathrm{N}$ MAR, but a model of recycled alkalic OIB or seamount basalts is equally plausible.

[5] We also use the data to assess the compatibilities of $\mathrm{Nb}$ and $\mathrm{Pb}$ (as well as Ta and $\mathrm{K}$ ) relative to other incompatible elements in two specific regions. These two elements are of special geochemical importance because they are widely used to discriminate between intraoceanic igneous processes on one side, and subduction-related processes and continental rocks on the other. Knowledge of the bulk partitioning of lead relative to other trace elements is also important in any discussion of the "lead paradox" [Allègre, 1969] and in the assessment of source compositions of oceanic basalts, where the use of experimental partition coefficients in silicate minerals can lead to very serious discrepancies [e.g., McKenzie et al., 2004]. Most previous such assessments have been made using global populations of MORB and OIB [Jochum et al., 1983; Hofmann et al., 1986], but with very limited data. This approach and the 


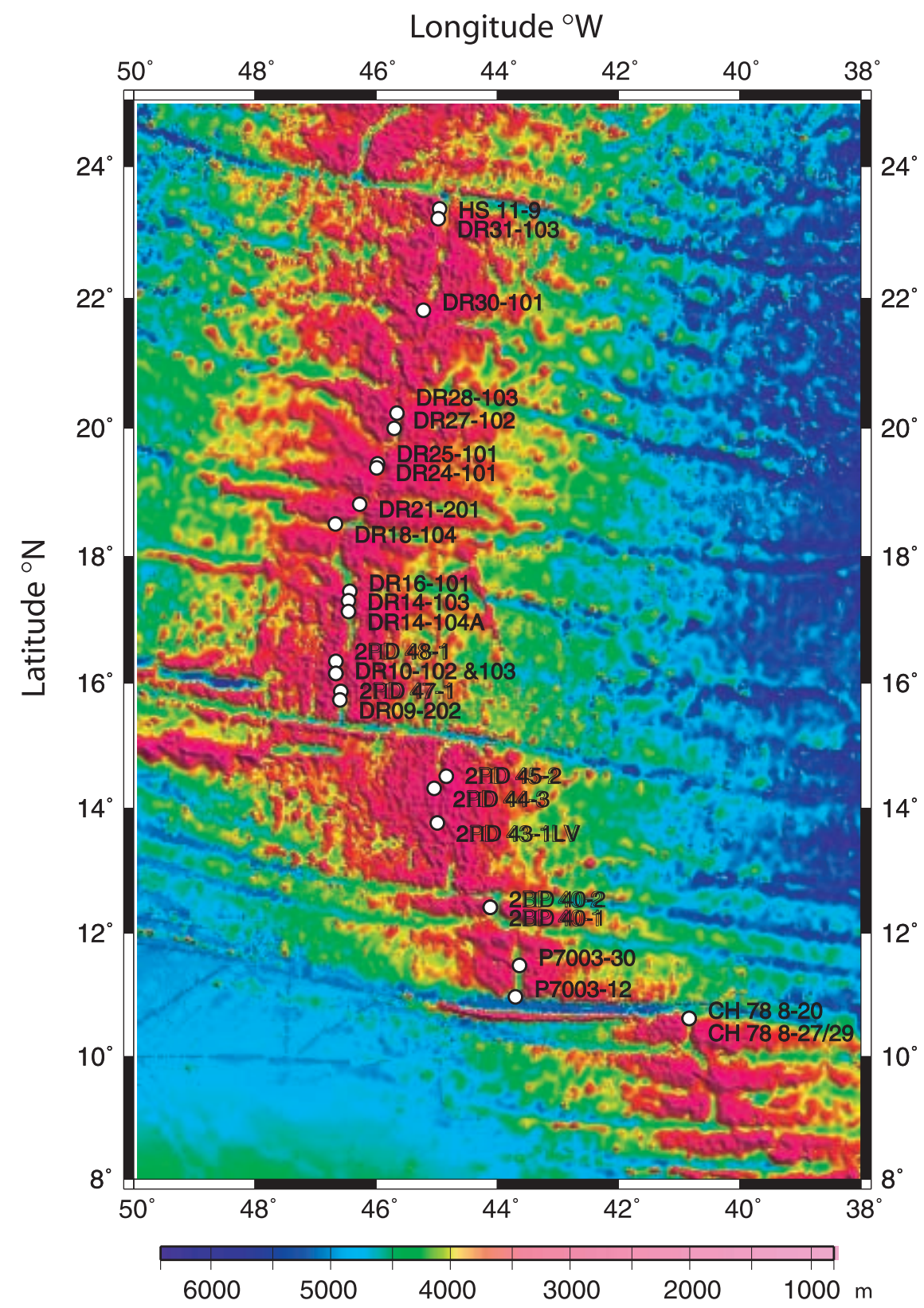

Figure 1. Bathymetry of the North Atlantic Ocean floor from 8 to $25^{\circ} \mathrm{N}$ and between 40 and $50^{\circ} \mathrm{W}$ from Smith and Sandwell [1994, 1997]. Sample locations are given as filled circles.

inferences drawn from it, has been criticized by Sims and DePaolo [1997], particularly with regard to $\mathrm{Ce} / \mathrm{Pb}$ ratios. These authors concluded, for example, that lead is significantly more compatible than cerium by factors of two to three during mantle melting processes. The compatibility of $\mathrm{Nb}$ has been re-assessed by Hofmann [2003], using new global MORB-OIB data and local OIB data from Iceland, but no new global assessment of the relative compatibility of lead has been published. Niu and Batiza [1997] assessed the sequence of trace element compatibilities from a large set of samples of near-ridge seamounts from the equatorial Eastern Pacific, using the same method as Hofmann et al. [1986]. They found that $\mathrm{Nb}$ is close to Th, and $\mathrm{Pb}$ close to $\mathrm{Pr}$ in compatibility. Our results, using a statistically more robust method, largely confirm this for N-MORB - E-MORB associations at 10$24^{\circ} \mathrm{N}$ MAR and south of the Marie Celeste Fracture Zone on the Central Indian Ridge. Although these results differ from the original analysis of Hofmann et al. [1986] in detail, they generally confirm its 


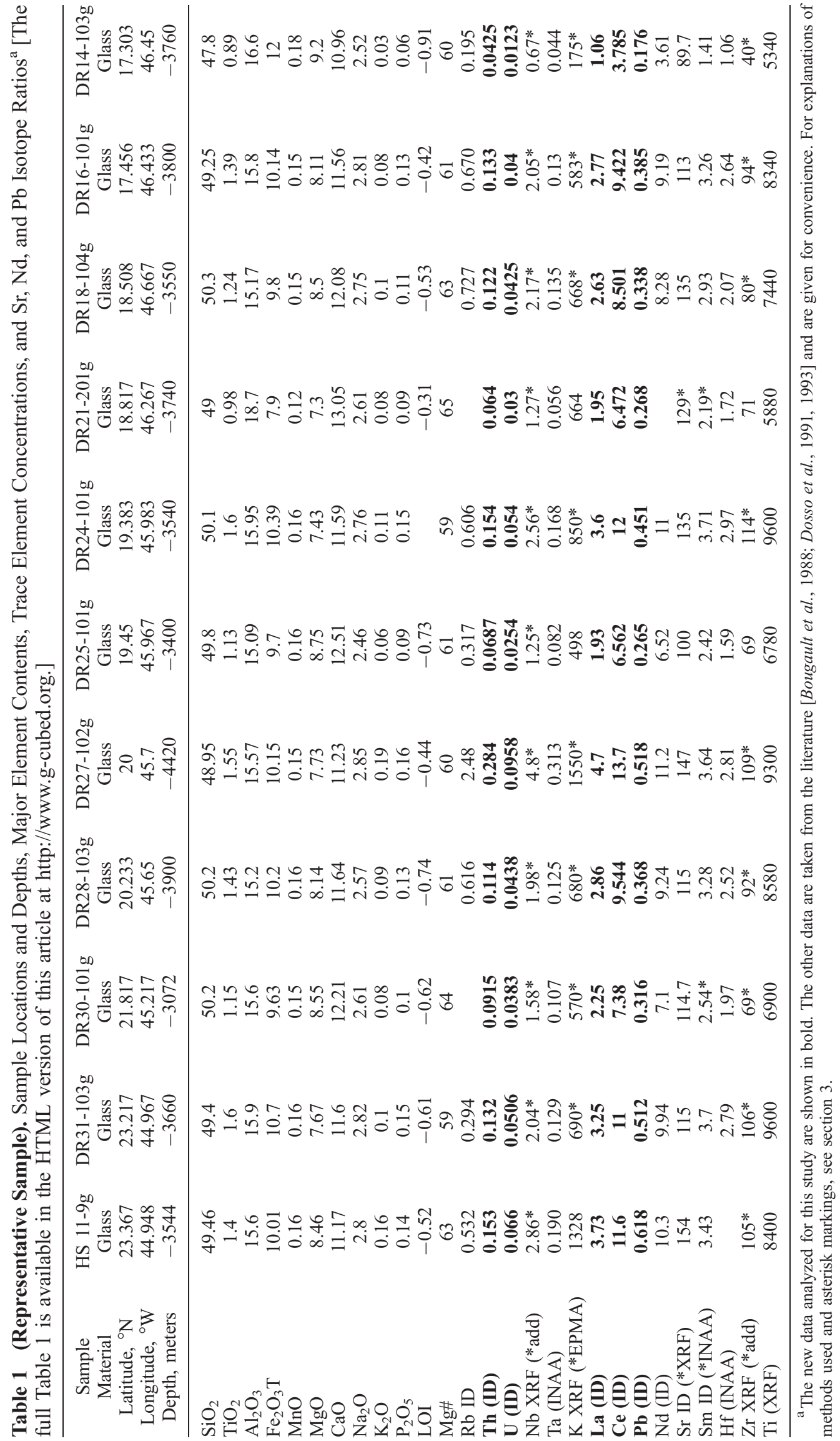




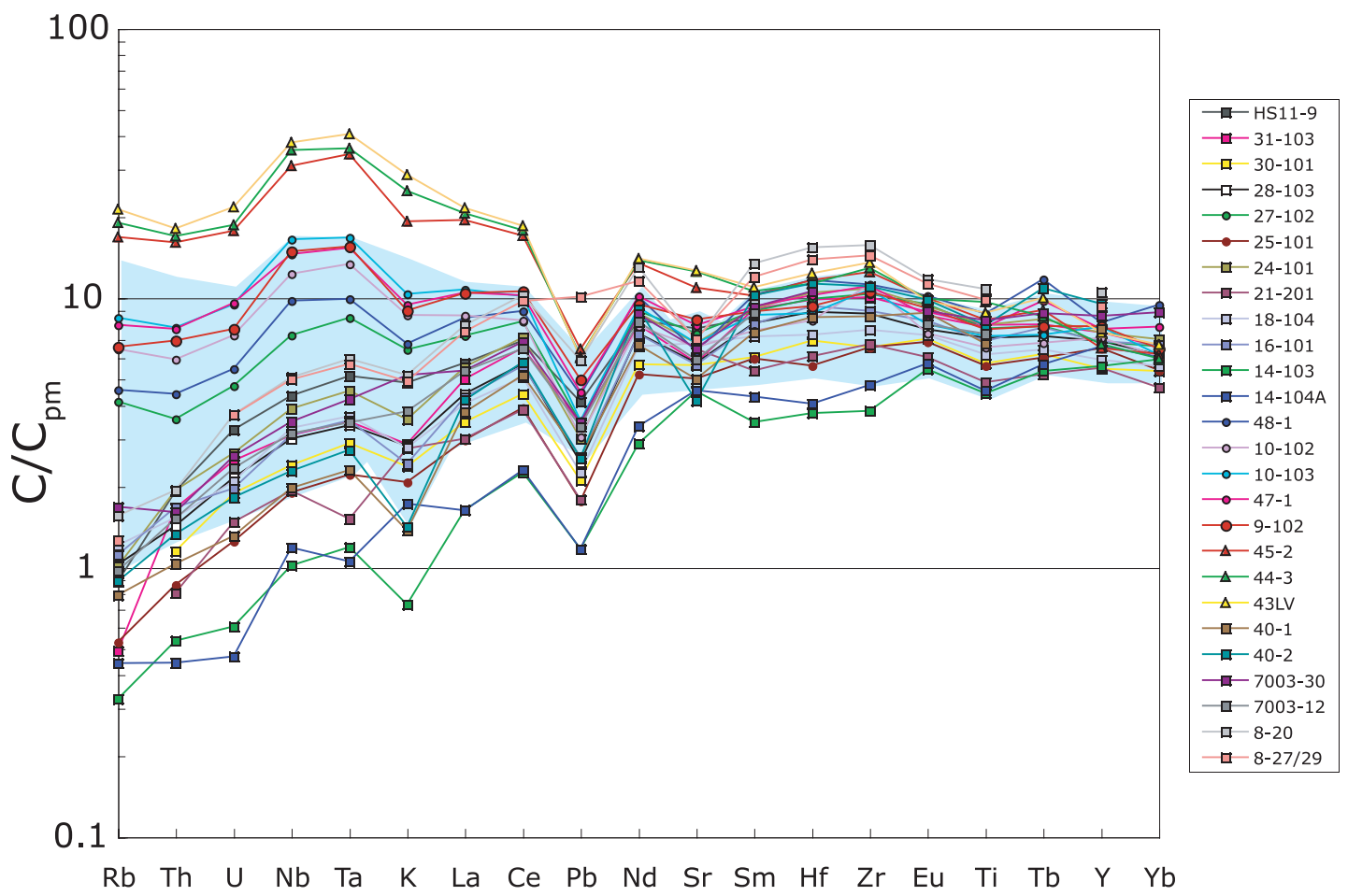

Figure 2. Primitive mantle normalized trace element abundances [McDonough and Sun, 1995]. Depleted N-MORB are shown as squares, intermediate "T-MORB" are shown as circles, and enriched E-MORB are shown as triangles. The shaded area corresponds to the samples of the Central Indian Ridge from Nauret et al. [2006] used for comparison in this paper.

broader conclusions and inferences concerning crust-mantle evolution.

\section{Samples}

[6] The samples analyzed here come from the MidAtlantic Ridge between $10^{\circ} \mathrm{N}$ and $24^{\circ} \mathrm{N}$, and their locations are shown on a bathymetric map (Figure 1). Because real bathymetric measurements are sparse and uneven, the so-called "predicted bathymetry" estimates the bathymetry of the global ocean basins using satellite altimetry. It is computed by deconvolving the free-air gravity anomaly derived from the altimetry by a theoretical admittance function, then by adjusting the longer wavelengths of the result to that of the real bathymetry using actual bathymetric tracks collected by ships [Smith and Sandwell, 1997]. In areas where real bathymetric data are available, these values supersede the computed ones in the $2^{\circ} \times 2^{\circ}$ grid provided by Smith and Sandwell [1997].

[7] The structure of the ridge includes several segments of various lengths separated by fracture zones (from North to South: Kane, $15^{\circ} 20$, Marathon, Mercurius and Vema fracture zones). Exact locations and depths of sample dredges have been reported in the work of Bougault et al. [1988] and Dosso et al. [1991, 1993] but are repeated in Table 1 for convenience. The depth of the dredges ranges from 3072 to $4600 \mathrm{~m}$. All samples were collected on the ridge axis, and 21 out of 26 consist of glassy fragments of pillow rims, 5 coming from pillow interiors. They are fractions of glass or rock powders coming from the same containers as that used in the publications mentioned above. They are all tholeiitic in composition and their Mg-numbers vary from 53 to 65 , suggesting that olivine extraction and/or accumulation remained limited.

\section{Analytical Techniques}

[8] All analyses were performed on powders previously prepared and used for isotope ratio and trace element content determinations [Bougault et al., 1988; Dosso et al., 1991, 1993]. About $100 \mathrm{mg}$ of sample were digested in Teflon Savillex (C) vials using distilled $\mathrm{HF}$ and $\mathrm{HCLO}_{4}$. Thorium and $\mathrm{U}$ 


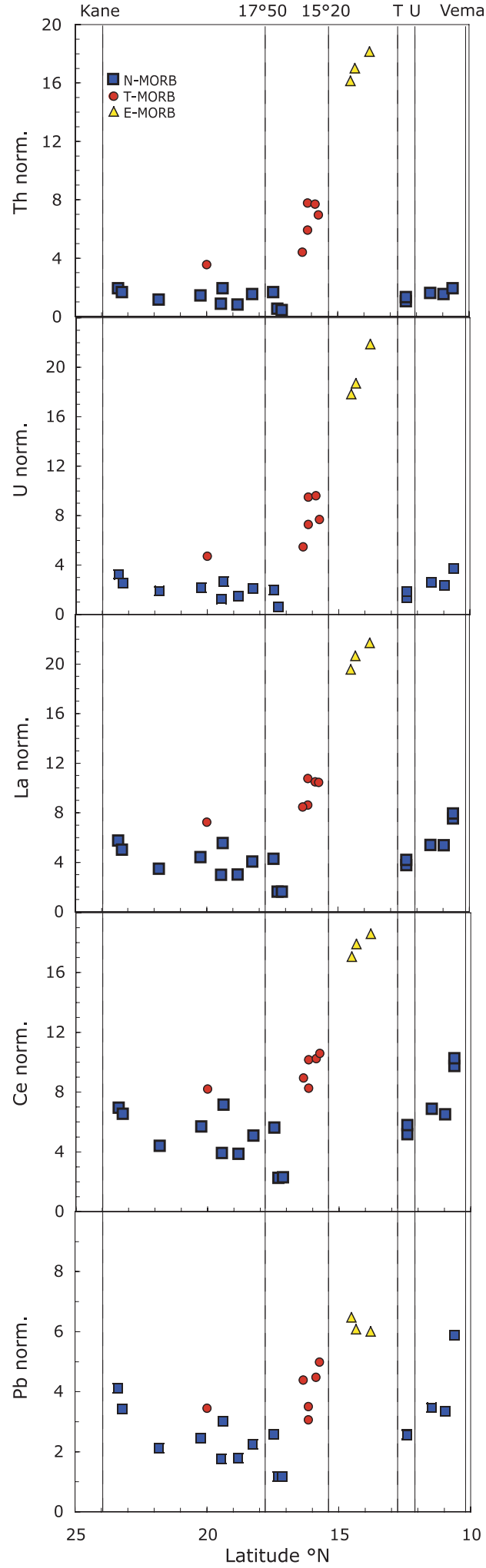

Figure 3. Along-ridge variations of $\mathrm{Th}, \mathrm{U}, \mathrm{La}, \mathrm{Ce}$, and $\mathrm{Pb}$ concentrations as functions of latitude. The relative magnitude of the concentration anomaly at $14-15^{\circ} \mathrm{N}$ diminishes from $\mathrm{Th}$ to $\mathrm{Pb}$ with increasing element compatibility. (N-MORB as blue squares, T-MORB as red circles, and E-MORB as yellow triangles.) were separated using the procedure described by Condomines et al. [1987], and $\mathrm{Pb}$ following the method of Manhès et al. [1984]. Lanthanum and Ce were separated following a protocol derived from Richard et al. [1976].

[9] Concentrations were measured by isotope dilution (ID) (using ${ }^{230} \mathrm{Th},{ }^{235} \mathrm{U},{ }^{206} \mathrm{~Pb},{ }^{138} \mathrm{La}$ and ${ }^{142}$ Ce spikes) on Finigan (C) MAT 261 and 262 mass spectrometers $(\mathrm{Pb}, \mathrm{La}$ and $\mathrm{Ce}$ on a MAT 261 in Brest, Th and U on a MAT 262 in Rennes). Thorium, $\mathrm{U}$ and $\mathrm{Pb}$ total chemistry blanks did not exceed 20, 10 and $300 \mathrm{pg}$, respectively, and are therefore negligible for the purpose of this paper. Lanthanum and Ce blanks were negligible at 70 and 200 pg, respectively. A glassy sample named MAPCO DR11 (from the North Atlantic Ridge at $30^{\circ} 40^{\prime} \mathrm{N} 41^{\circ} 49^{\prime} \mathrm{W}$ ), similar in composition to the samples analyzed in this study, was repeatedly analyzed and yielded $U=0.0382 \pm 0.0005$ $(\mathrm{n}=12), \mathrm{Th}=0.0998 \pm 0.0011(\mathrm{n}=11), \mathrm{Pb}=0.827 \pm$ $0.025(\mathrm{n}=5), \mathrm{La}=2.59 \pm 0.16(\mathrm{n}=5), \mathrm{Ce}=8.59 \pm$ $0.12(n=6)(2 \sigma$ standard deviations). The relatively large standard deviation of the $\mathrm{Pb}$ concentrations does not come from the blank (300pg) but is probably related (1) to the heterogeneous distribution of metal sulfides in submarine glasses and (2) to the relatively small size of the samples (small glass fragments).

[10] The other trace element data used in this paper have been published in previous papers [Bougault et al., 1988; Dosso et al., 1991, 1993]. All niobium (and most of the $\mathrm{Zr}$ and $\mathrm{Y}$ ) concentrations but two were measured by X-ray fluorescence (XRF) doping technique [Etoubleau et al., 1991]. In Table 1, they are marked by "*add". Other trace elements were determined using conventional XRF techniques (see references above for published data). Rubidium, Sr (except one sample), $\mathrm{Nd}$ and all but two Sm concentrations were measured using isotope dilution. Two Sm concentrations (DR30-101 and DR21-201), as well as all Ta, $\mathrm{Hf}, \mathrm{Eu}, \mathrm{Tb}$ and $\mathrm{Yb}$ data, were obtained by instrumental neutron activation analysis (INAA, CEA Saclay, J.-L. Joron, analyst). Potassium concentrations were measured and crosschecked using isotope dilution, electron microprobe analysis (exclusively on glass fragments) or XRF [see Dosso et al., 1993]. Titanium was determined as $\mathrm{TiO}_{2}$ using conventional XRF technique for major elements. When two analytical techniques were used for the same element, they are marked in the first column of Table 1 by an asterisk and a label ("add" for the doping method, EPMA, XRF 


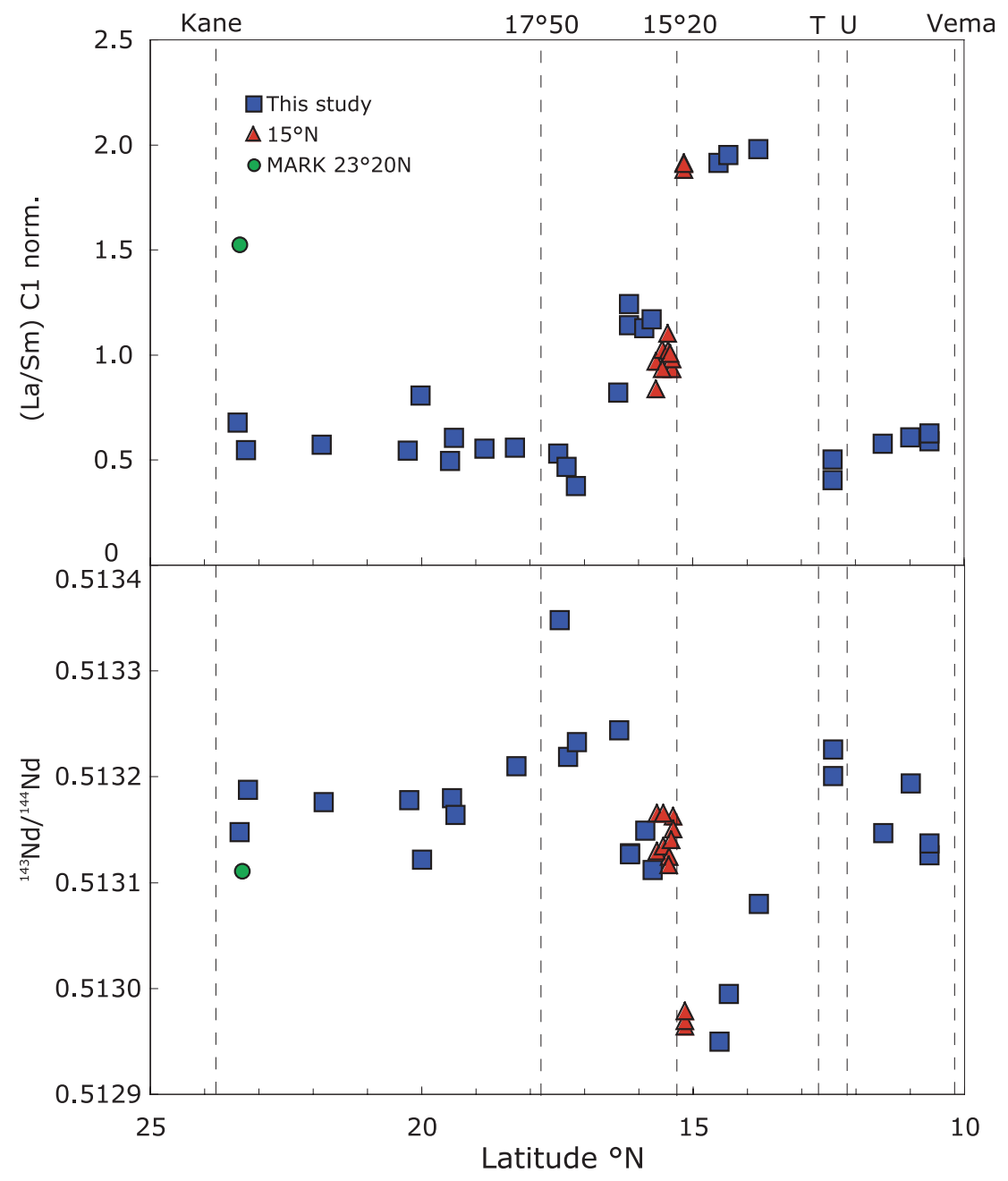

Figure 4. $(\mathrm{La} / \mathrm{Sm})_{\mathrm{C} 1}$ normalized ratios and $\mathrm{Nd}$ isotope ratios versus latitude. Blue squares represent the samples of this study, red triangles are unpublished data from P. Nonotte (DEA, Brest, 2003), and the green circle is the E-MORB from the MARK area [Donnelly et al., 2004].

or INAA for electron probe microanalysis, X-ray fluorescence and instrumental neutron activation analysis, respectively).

\section{Results}

[11] Thorium, $\mathrm{U}, \mathrm{La}, \mathrm{Ce}$ and $\mathrm{Pb}$ data are given in Table 1. Th, U, and La concentrations range from 0.035 to 1.44 , from 0.010 to 0.443 , and from 1.1 to $14.0 \mathrm{ppm}$, respectively. Lead concentrations vary from $0.176 \mathrm{ppm}$ to $0.969 \mathrm{ppm}$. Sample DR8-27/29 has an abnormally high $\mathrm{Pb}$ concentration, three times higher than that of DR27-102, which has very similar other trace element concentrations. This sample probably contains some excess sulfide, and it will be treated as an outlier not to be used in correlations of $\mathrm{Pb}$ with other trace elements. These variations represent about one third of the total concentration variations of the global spreading system.

[12] The results are shown in Figure 2 in the form of conventional spidergrams (measured concentrations normalized to primitive-mantle abundances given by [McDonough and Sun, 1995].

\section{Discussion}

\subsection{Along-Ridge Variations}

[13] Figure 3 shows the abundance variations of the five newly measured (normalized) trace elements as well as sample depths as a function of latitude along the MAR. Abundances vary by up to a factor of 40 and reach a maximum between 14 and $15^{\circ} \mathrm{N}$. 

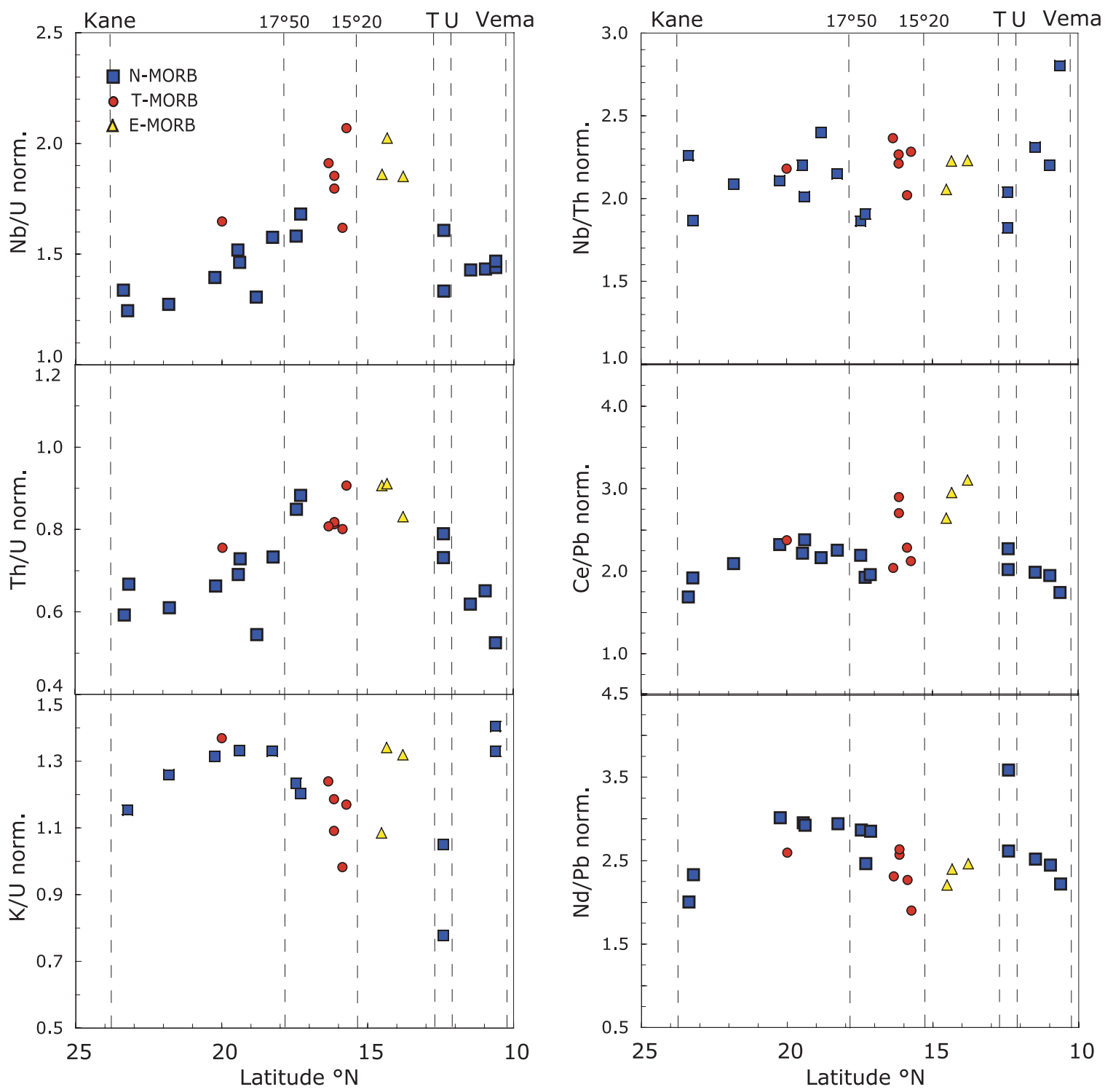

Figure 5. Along-ridge variations of selected trace element ratios. The canonically "uniform" ratios of $\mathrm{Nb} / \mathrm{U}$ and $\mathrm{Ce} / \mathrm{Pb}$ (as well as $\mathrm{Th} / \mathrm{U}$ ) increase significantly at $14-15^{\circ} \mathrm{N}$, whereas $\mathrm{Nb} / \mathrm{Th}$ and $\mathrm{K} / \mathrm{U}$ show no systematic variations. $\mathrm{Nd} / \mathrm{Pb}$ shows a slight decrease (complementary to $\mathrm{Ce} / \mathrm{Pb}$ ) at the same latitude, indicating the $\mathrm{Pr} / \mathrm{Pb}$ (not analyzed) should be essentially uniform. (N-MORB as blue squares, T-MORB as red circles, and E-MORB as yellow triangles.)

Water depths show no obvious correlation with trace element enrichment, although the general bathymetry has a weakly developed high in the ridge segment between 12.8 and $15.2^{\circ} \mathrm{N}$. We also note that in this segment there is a short line of seamounts starting about $300 \mathrm{~km}$ to the west of the ridge, but there is no clear connection between them and the ridge. As expected, ratios of incompatible to more compatible elements, for example $\mathrm{La} / \mathrm{Sm}$, and isotope ratios, e.g. ${ }^{143} \mathrm{Nd} /{ }^{144} \mathrm{Nd}$, show similar regional variations from $\mathrm{N}-\mathrm{MORB}$ to E-MORB character (Figure 4). Overall, there is not tangible evidence for any plume activity in this region, and although Bougault et al. [1988] and Dosso et al. [1991] had suggested the possibility of an incipient plume, more recent discussions by the same authors focused on other types of upper-mantle enrichment in this area [Dosso et al., 1993].

[14] Trace element ratios often thought to be more directly representative of source compositions than $\mathrm{La} / \mathrm{Sm}$, namely $\mathrm{Nb} / \mathrm{U}, \mathrm{Ce} / \mathrm{Pb}, \mathrm{K} / \mathrm{U}$ and $\mathrm{Th} / \mathrm{U}$, are shown in Figure 5 . The $\mathrm{Nb} / \mathrm{U}$ and $\mathrm{Th} / \mathrm{U}$ ratios do show significant regional variations, whereas $\mathrm{Nb} / \mathrm{Th}$ and $\mathrm{K} / \mathrm{U}$ do not. The slight positive excursion of the $\mathrm{Ce} / \mathrm{Pb}$ in the 14 


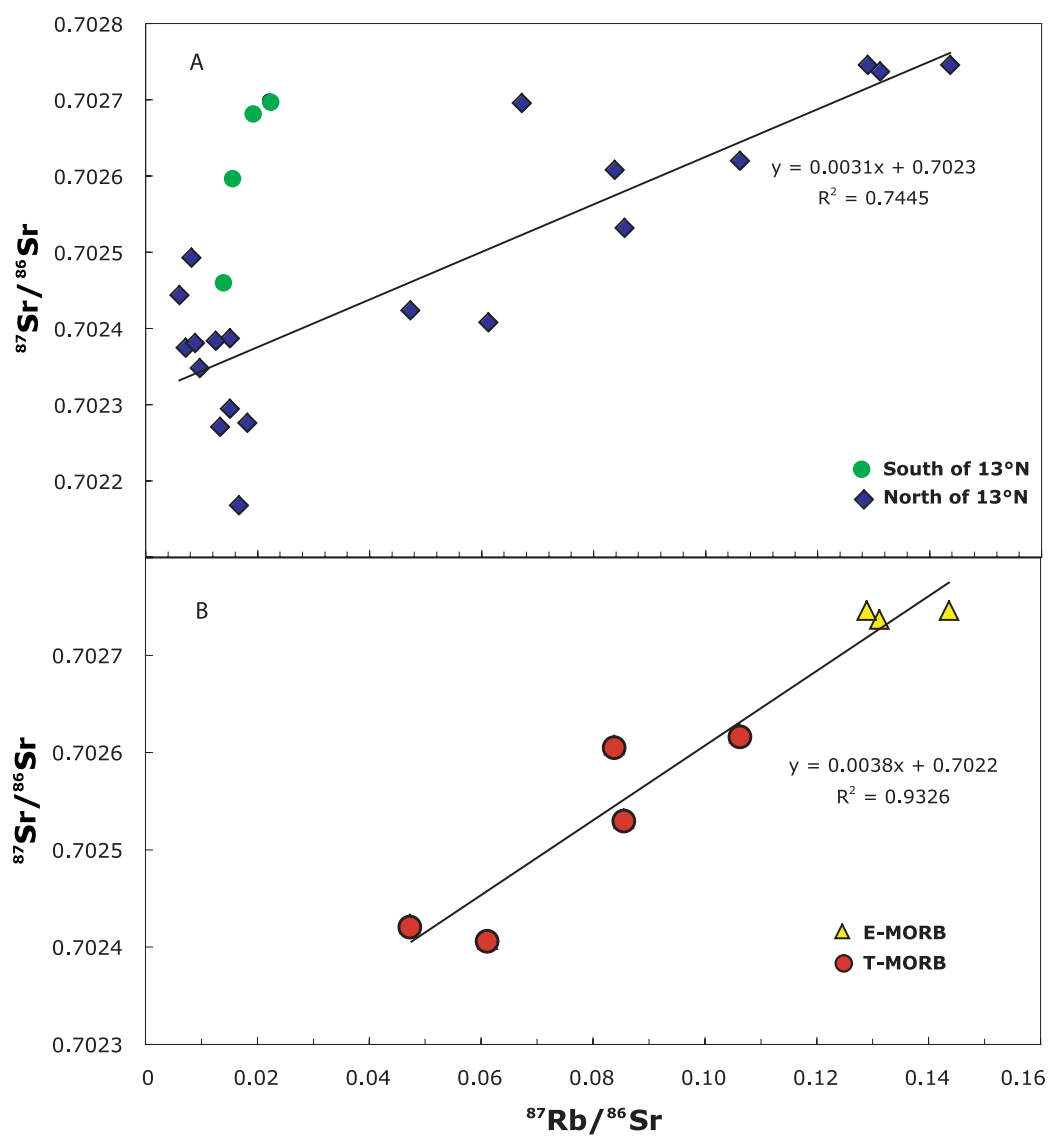

Figure 6. ${ }^{87} \mathrm{Sr} /{ }^{86} \mathrm{Sr}$ versus ${ }^{87} \mathrm{Rb} /{ }^{86} \mathrm{Sr}$. The entire data set presented in Figure 6a shows a weak overall correlation $(\mathrm{r}=0.68)$ (all samples north of $13^{\circ} \mathrm{N}$ as blue squares and others, south of $13^{\circ} \mathrm{N}$, as green circles) which improves greatly $(r>0.95)$ in Figure $6 \mathrm{~b}$ when restricted to T- and E-MORB (red circles and yellow triangles, respectively).

$15^{\circ} \mathrm{N}$ region is mirrored by a complementary negative excursion of $\mathrm{Nd} / \mathrm{Pb}$, so that the intermediate $\mathrm{Pr} / \mathrm{Pb}$ (not measured) should be approximately invariant. Further below, we reexamine the compatibilities of $\mathrm{Nb}, \mathrm{K}$, and $\mathrm{Pb}$ relative to other, similarly incompatible, elements in this region of the MAR.

\subsection{Origin of E-MORB at $14^{\circ}-15^{\circ} \mathrm{N}$}

\subsubsection{Previous Works}

[15] Correlations between trace element ratios and isotopes along the MAR between $10-24^{\circ} \mathrm{N}$ [Bougault et al., 1988; Dosso et al., 1991, 1993] have been ascribed to an interaction between an incipient plume and the depleted upper mantle, suggesting that the $14^{\circ} \mathrm{N}$ anomaly may coincide with the triple junction between the South American, North American and the African plates. In this model, the geochemical spike would be caused by upwelling of deeper mantle in this area mixing with the upper mantle. Recently, systematic relationships between parent/daughter element ratios and isotope ratios have been identified along the $10-24^{\circ} \mathrm{N}$ and $31-41^{\circ} \mathrm{N}$ MAR sections [Dosso et al., 1999] and modeled as resulting from an enrichment event in a depleted heterogeneous mantle at $200 \pm 100 \mathrm{Ma}$. According to these authors, the coincidence between this age and that of the pre-opening of the North Atlantic "raises the possibility that some of the heterogeneity in this region is associated with shallow level mantle heterogeneity resulting from the rifting of Gondwanaland rather than from interaction with mantle plumes."

\subsubsection{Is the Enrichment Inherited From the Source or Produced by Partial Melting Effects?}

[16] To evaluate whether trace element enrichments are present in the mantle sources of the basalts or are caused purely by melting effects, it is useful to search for correlations between incompatible trace element and isotope ratios. Figure $6 \mathrm{a}$ 

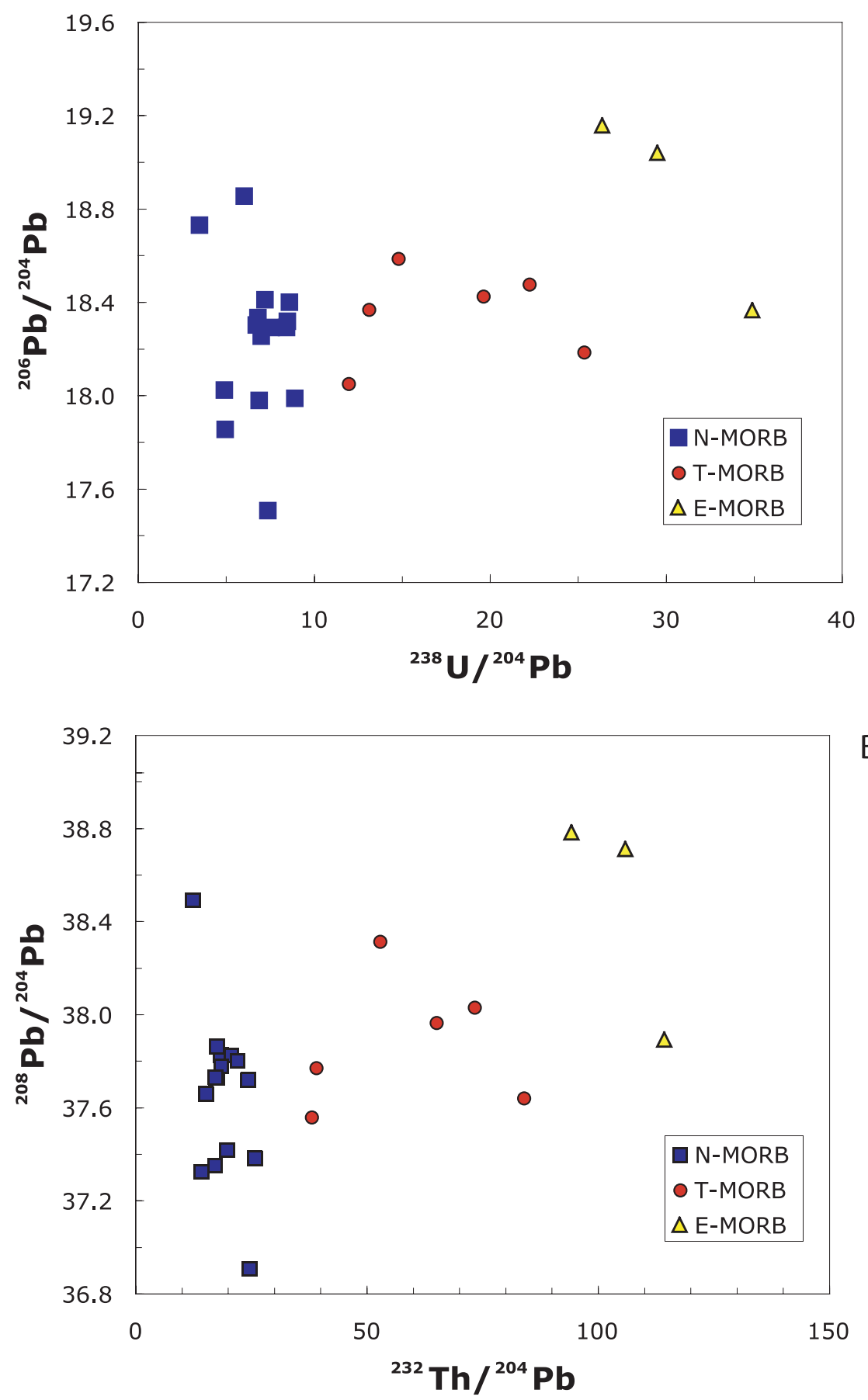

Figure 7. $\mathrm{Pb}$ isochron diagrams (a) ${ }^{206} \mathrm{~Pb} /{ }^{204} \mathrm{~Pb}$ versus ${ }^{238} \mathrm{U} /{ }^{204} \mathrm{~Pb}$ and $(\mathrm{b}){ }^{208} \mathrm{~Pb} /{ }^{204} \mathrm{~Pb}$ versus ${ }^{232} \mathrm{Th} /{ }^{204} \mathrm{~Pb}$.

shows $\mathrm{Rb} / \mathrm{Sr}$ versus ${ }^{87} \mathrm{Sr} /{ }^{86} \mathrm{Sr}$. This shows only a relatively weak overall correlation $(r=0.68)$, which is nevertheless significant at the $99 \%$ confidence level. When the samples are geographically restricted to the enriched region around $14-15^{\circ} \mathrm{N}$ (Figure $6 \mathrm{~b}$ ), the quality of the correlation improves greatly $(r>0.95$, and we effectively obtain a Rb-Sr pseudo isochron (with a nominal age of about $270 \mathrm{Ma}$ ) very similar to those described by
Donnelly et al. [2004] for the MARK area and several other E-MORB regions. Similarly, the U-Pb and $\mathrm{Th}-\mathrm{Pb}$ "isochron" diagrams (Figure 7) also show more poorly defined positive trends with correlation coefficients of 0.43 and 0.53 for ${ }^{206} \mathrm{~Pb} /{ }^{204} \mathrm{~Pb}$ versus $\mathrm{U} / \mathrm{Pb}$ and ${ }^{208} \mathrm{~Pb} /{ }^{204} \mathrm{~Pb}$ versus $\mathrm{Th} / \mathrm{Pb}$, respectively. Both of these correlations also become stronger when the samples are restricted to the enriched region. Overall, these 


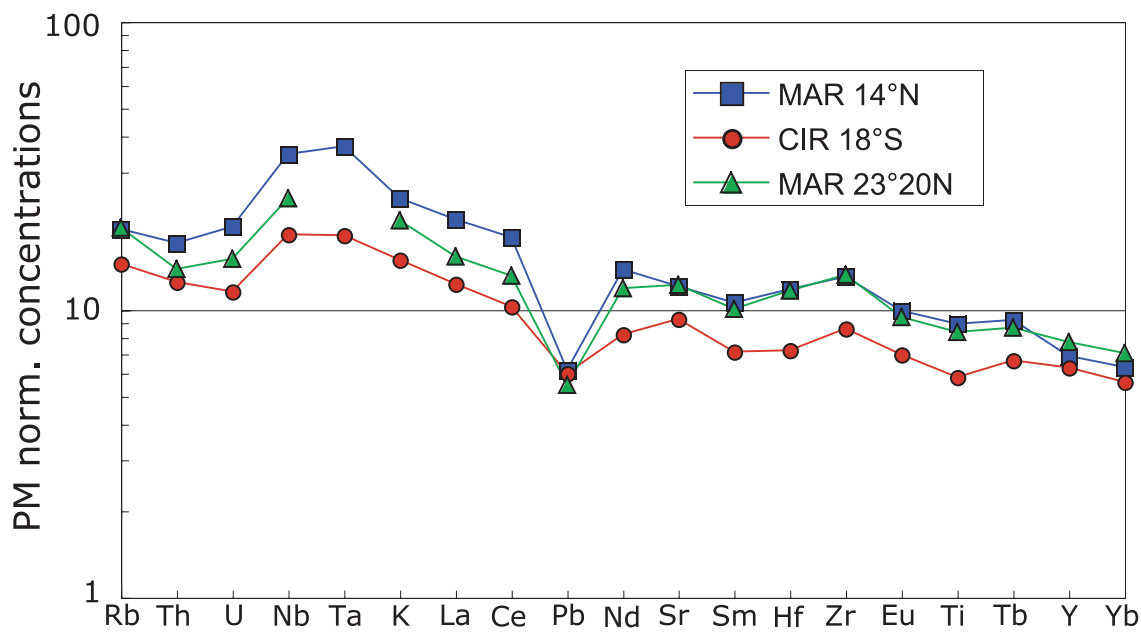

Figure 8. Comparison between E-MORB from $14-15^{\circ} \mathrm{N}$ on the Mid-Atlantic Ridge (MAR), $18^{\circ} \mathrm{S}$ on the Central Indian Ridge [Nauret et al., 2006], and the MARK area at $23^{\circ} 20^{\circ} \mathrm{N}$ on the MAR [Donnelly et al., 2004].

correlation plots are consistent with the inference that the geochemical variations observed in the region reflect primarily source heterogeneity.

[17] Another, at least equally compelling reason to conclude that the enrichment is predominantly a source feature is the enormous difference in the abundances of the most highly incompatible elements. To generate a difference of a factor of 40 in $\mathrm{Th}, \mathrm{Rb}$, and $\mathrm{Nb}$ abundances purely by differences in melt fraction, cumulative melt fractions would have to vary by a similar factor, for example from $0.5 \%$ to $20 \%$, a range that is inconsistent with our understanding of the petrology of such melts, in particular with the very similar $\mathrm{Na}_{2} \mathrm{O}$ contents $\left(\mathrm{Na}_{8.0}\right.$ averages vary only between 2.77 in N-MORB and 2.79 in T- and E-MORB, respectively). According to Klein and Langmuir [1987], this would indicate a melt fraction of about $10 \%$ with a variation of no more than a few percent. If this is correct, the correlations of trace element enrichment with isotope ratios can be explained by a relatively recent age (or ages) of source differentiation [see also Dosso et al., 1999]. The widespread occurrence of such apparently young differentiation ages has led Donnelly et al. [2004] to postulate a process of continuous differentiation and mixing in the MORB-source mantle using a mathematical model earlier set out by Albarède [2001]. Our data on $14-15^{\circ} \mathrm{N}$ MAR are fully consistent with this theory.

\subsubsection{Origin of the Enriched Source}

[18] Figure 8 shows a comparison of E-MORB compositions from $14^{\circ} \mathrm{N}$ with two other E-MORB, one from the Central Indian Ridge [Nauret et al.,
2006], and one from the MARK area described by Donnelly et al. [2004]. In both cases, a direct influence by a mantle plume was effectively ruled out by the authors. Donnelly et al. noted that this kind of enrichment requires melting at a low melt fraction at some stage during the history of such melts. Since such low melt fractions are unlikely to occur in mid-ocean ridge environments, which are generally characterized by relatively high melt fractions, recycled depleted, N-type MORB do not constitute suitable sources for such E-MORB. Therefore Donnelly et al. [2004] developed a model whereby the source of such MORBs is enriched by a metasomatic process in which a low-degree melt infiltrates oceanic lithospheric mantle, either near an oceanic ridge or during subduction. This creates an enriched peridotite or peridotite-eclogite source, which is recycled into a new ridge environment where it can generate enriched MORB even at relatively high degrees of melting. It is obvious that such a model can also be applied to the enriched basalts of the CIR and $14^{\circ} \mathrm{N}$ MAR shown in Figure 8 , since all three basalts have very similar compositions.

[19] Although the metasomatic model mentioned above can explain the chemical characteristics of E-MORB quite well, it is worth exploring alternative enrichment processes. The ocean-crust recycling mechanism [Hofmann and White, 1982] is often criticized on the grounds that "normal" or average MORB are too depleted to serve as suitable sources of many OIBs. But subduction introduces many types of ocean crust into the mantle, not just average "N-MORB." We note that the essential requirement for generating the appropriate enrichment in the E-MORB source is a previous 


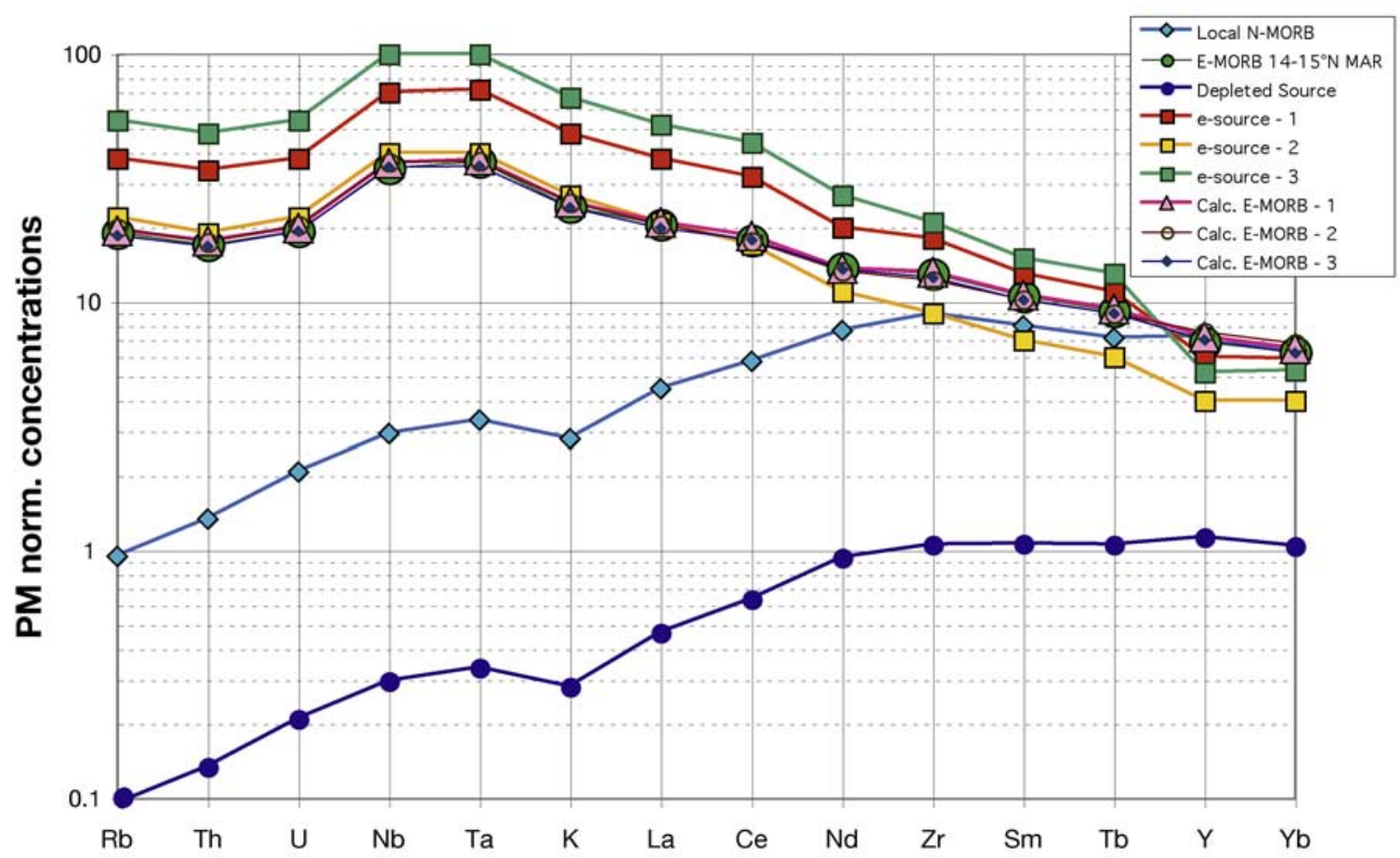

Figure 9. E-MORB modeling, showing three hypothetical alkali basalt compositions (e-source -1 , e-source -2 , and e-source -3 ) which are recycled and mixed with local depleted mantle in mixing ratios of $0.1: 1,0.16: 1$, and $0.05: 1$, respectively. These mixed, enriched sources are then subjected to simple batch melting $(20 \%, 18 \%$, and $15 \%)$ to yield a melt composition matching the observed average E-MORB at $14-15^{\circ} \mathrm{N}$ MAR. The local depleted mantle ("Depleted Source") is modeled from the locally observed average N-MORB assuming 10\% batch melting. Modal melting proportions and partition coefficients are those used by Donnelly et al. [2004] (for full references, see text). The matches between all three calculated and observed E-MORB are essentially perfect because starting compositions and other parameters of the model have been chosen to yield this result.

stage of very low degree melting. Intraplate oceanic basalts found on ocean islands and on many seamounts [Batiza, 1982] are in most cases alkalic and incompatible-element enriched, and they constitute an observable, extremely common product of such low melt fractions. Most of these basaltic ocean islands and seamounts must be subducted with the remainder of the oceanic crust and lithosphere, and we would find it surprising if they did not eventually resurface in recycled form. Hofmann [1989] had briefly explored such processes to account for the compositions of many plume basalts. McKenzie et al. [2004] have invoked recycling of this type quantitatively to explain the compositions of several OIB suites. Donnelly et al. reject this as an acceptable mechanism for generating E-MORB sources on the grounds that OIBs are too radiogenic in $\mathrm{Sr}$ and $\mathrm{Pb}$ isotopes, and too unradiogenic in $\mathrm{Nd}$, and could therefore not yield the isotopic compositions of E-MORBs upon recycling. Although this is true for average OIB, there is also enormous overlap in the range of isotopic compositions observed in OIBs and
MORBs [e.g., Hofmann, 2003]. Specifically, some of the E-MORB suites have isotopic compositions well in the range of ordinary OIBs $\left({ }^{87} \mathrm{Sr} /{ }^{86} \mathrm{Sr}=0.7030\right.$ to 0.7035 ; e.g., those from the SEIR and the MAR $31-38^{\circ} \mathrm{N}$ cited by Donnelly et al. [2004] and the CIR suite described by Nauret et al. [2006]). There are also OIBs and seamounts containing alkalic or transitional basalts with isotope ratios of ${ }^{87} \mathrm{Sr} /{ }^{86} \mathrm{Sr}<0.703$. These include the island of Madeira, several of the Galapagos Islands, some of the Austral-Cook Islands, Iceland, seamounts from the Pukapuka Ridge and from $5-15^{\circ} \mathrm{N}$ near the EPR. Thus depleted mantle sources are clearly capable of generating enriched basalts, presumably by low degrees of melting in regions of sufficiently thick lithosphere. It is not known which proportion of such melts extrudes to the ocean floor and which proportion remains in the mantle, but some of them certainly do extrude. In any case, the wide ranges of both MORB and potentially recycled OIB compositions can hardly constrain the isotopic compositions of specific E-MORB occurrences. Since 


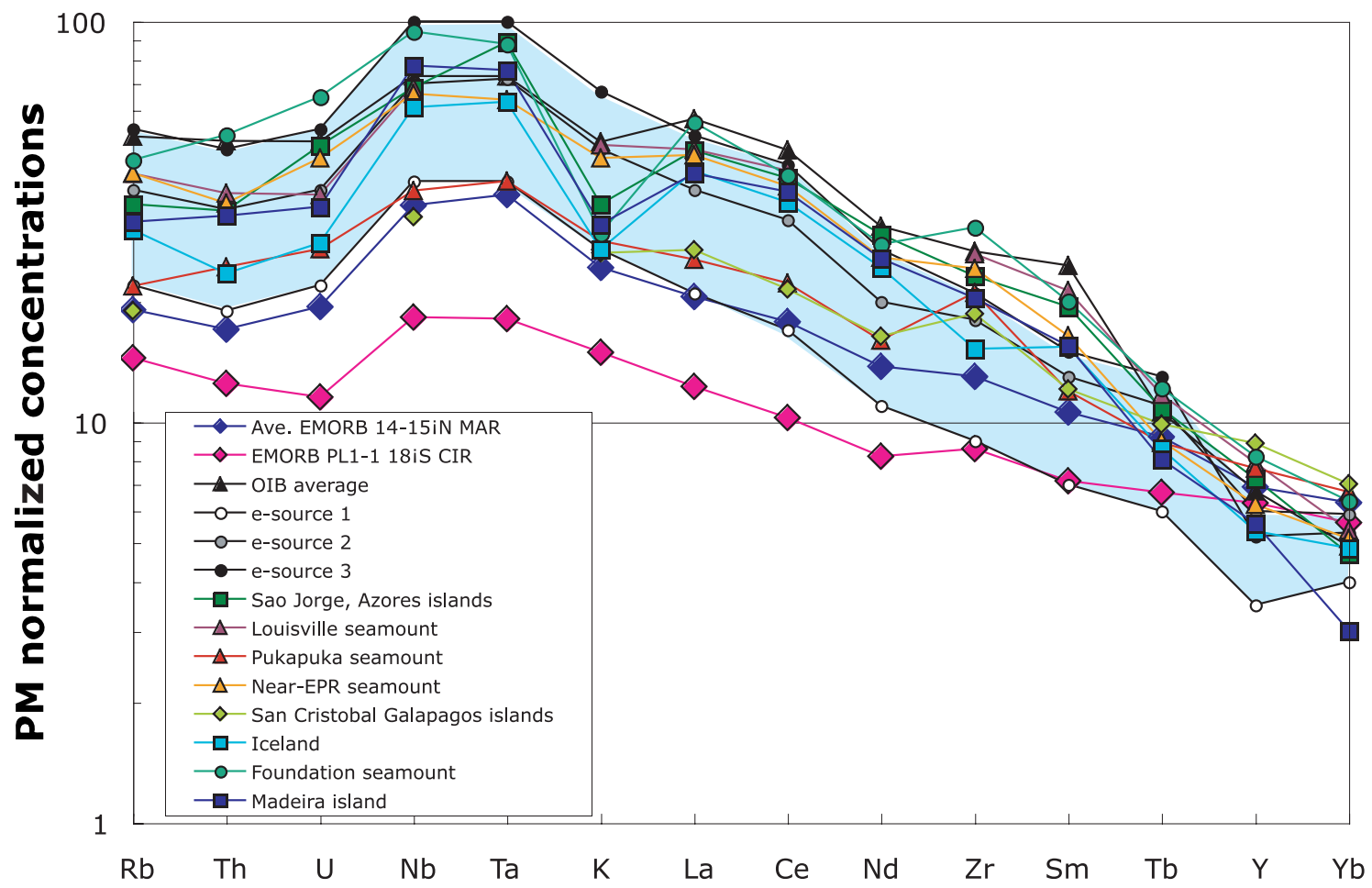

Figure 10. Examples of alkali basalt compositions from oceanic islands and seamounts resembling the range of assumed "e-sources" in Figure 9, shown here as a shaded field. Most of these examples were selected by casual inspection of the GEOROC database. The average E-MORB from $14-15^{\circ} \mathrm{N}$ MAR and from $18^{\circ} \mathrm{S} \mathrm{CIR}$ are shown for comparison. The alkali basalts plotted as examples are from the following sources: Azores, Sao Jorge island, SJ-31B $\left({ }^{87} \mathrm{Sr}{ }^{86} \mathrm{Sr}=0.70348\right)$ from Turner et al. [1997], Louisville SOTW52-1 (0.703396) from Cheng et al. [1987] and Hawkins et al. [1987], Pukapuka seamounts 9DS2 (0.702938) from Janney et al. [2000], Galapagos San Cristobal island E-103 (0.70281) from White et al. [1993], $5^{\circ}-15^{\circ} \mathrm{N}-\mathrm{EPR}$ seamounts R15-1 (0.702877) from Niu et al. [2002], Iceland H91 (0.703362) from Kokfelt et al. [2003], Foundation seamount chain, Buffon seamount 28GTV1 (0.702731), unpublished trace element data from C. Devey, Madeira island M19 (0.70268) from Mata et al. [1998], and OIB average from Sun and McDonough [1989].

it is now well accepted that mantle convection can be quite inefficient in homogenizing what is being subducted, it seems inevitable that some of this alkalic, enriched material is recycled, not only in plumes but also in ordinary ocean ridges.

[20] An important question in the context of the recycling model is, to what extent the subducted rocks have been altered prior to subduction and further modified by mobilization processes during subduction [see, e.g., Eisele et al., 2002; Stracke et al., 2003]. We emphasize that the extent to which such modifications have affected specific subducted rock assemblages is essentially unknown. Therefore, following the approach by McKenzie et al. [2004], we initially ignore such modifications, i.e., we assume that the subducted rocks were fresh and were not modified during subduction. Ultimately, it will be seen that the validity of this simplified approach is justified by the absence of significant evidence of alteration. Such evidence should be found in the relative abundances of such alteration-sensitive elements as uranium and potassium, which would be expected to have much more variable abundances than alteration-resistant elements such as $\mathrm{Th}, \mathrm{Nb}$ or La.

[21] In Figure 9 we show the results of very simple model calculations to illustrate such a recycling process. The specific examples chosen start with the subduction of hypothetical, but rather typical oceanic alkali basalts, which upon recycling are mixed with a depleted mantle calculated from the composition of the depleted basalts found in the ridge segments to the north and south of 14$15^{\circ} \mathrm{N}$ MAR. The three hypothetical alkali basalts ("e-source-1, -2, and-3") have $\mathrm{Nb}$-Ta abundances ranging from 40 to 100 times primitive. Their abundance patterns were chosen so that the final model product matches the observed, average E-MORB at $14-15^{\circ} \mathrm{N}$ exactly. We then checked whether these hypothetical compositions can be 
matched by observed oceanic alkali basalts; see Figure 10 and discussion below. In the case of e-source-1, $10 \%$ of such alkali basalt is added to the local, depleted source. This mixed source is then subjected to simple batch melting (melt fraction $F=0.2$ ) to produce the observed E-MORB composition. The less enriched e-source-2 is mixed with the depleted source in a ratio of $0.16: 1$, and the final melt fraction is reduced to $18 \%$. The more enriched e-source-3 is mixed in a ratio of $0.05: 1$, and the final melt fraction is $15 \%$. The partition coefficients are identical to those used by Donnelly et al., and are taken from various sources [Beattie, 1993; Blundy and Wood, 1994; Hanson, 1980; Hart and Dunn, 1993; Johnson, 1994; Kelemen et al., 1993; Kennedy et al., 1993; Salters and Longhi, 1999; Wood and Blundy, 1997]. Source and melting modes are also taken from the paper of Donnelly et al. [2004]. We use relatively high final melt fractions because of the enhanced fertility of the mixed source. Clearly, these examples are not unique, and other initial compositions and combinations of mixing ratios, melt fractions, and melting processes could be chosen to match the observed final composition, but there seems little point in attempting to cover all conceivable recycling situations.

[22] Figure 10 shows actual examples of oceanic alkali basalts with compositions close to our hypothetical starting compositions. These examples were chosen somewhat arbitrarily by inspection of GEOROC database compositions, but with an emphasis on isotopically "depleted" samples with ratios of ${ }^{87} \mathrm{Sr}{ }^{86} \mathrm{Sr}<0.703$ and similar to the E-MORBs at $14^{\circ}-15^{\circ} \mathrm{N}$ MAR and the MARK area. They resemble the range of hypothetical e-sources fairly well. Clearly, the source enrichment needed both for our model and that of Donnelly et al. is such that it would lead to much more radiogenic $\mathrm{Sr}$ (and less radiogenic $\mathrm{Nd}$ ) compositions, if the age of enrichment were similar to what is commonly suggested for mantle plume sources, namely 1 to $2 \mathrm{Ga}$. This is also evident from the $\mathrm{Rb}-\mathrm{Sr}$ isochron plot shown in Figure $6 \mathrm{~b}$ (and in those shown by Donnelly et al. [2004]), which corresponds to an apparent age of about $270 \mathrm{Ma}$. This means that either the recycling timescale must be comparatively rapid for EMORB reservoirs, or the process resembles the steady state model of differentiation and remixing as modeled by Albarède [2001] and by Donnelly et al. [2004]. Such continuous mantle processes could apply similarly to subducted OIBs as to metasomatized lithosphere. We conclude that recycling of oceanic alkali basalts appears to be a simple and geologically plausible, essentially uniformitarian way to account for the E-MORB phenomenon. This does not, of course, rule out the possibility of more "exotic," metasomatic enrichment processes such as the one discussed by Donnelly et al. [2004].

\subsection{Relative Compatibility Analysis}

[23] In an effort to determine a measure of relative compatibilities of trace elements in mantle-derived basalts, Hofmann et al. [1986] introduced a criterion based on simple equilibrium melting theory originally outlined by Minster and Allègre [1978] and subsequently simplified by Hofmann and Feigenson [1983] which used the slopes of diagrams of the form $\mathrm{C}_{1} / \mathrm{C}_{2}$ versus $\mathrm{C}_{1}$ to evaluate relative partition coefficients during melting. Accordingly, basalt data arrays with positive slopes in this parameter space indicate $D_{1}<D_{2}$, arrays with negative slopes indicate $\mathrm{D}_{1}>\mathrm{D}_{2}$, and arrays with zero slope indicate $\mathrm{D}_{1}=\mathrm{D}_{2}$. This has the advantage that constant trace element ratios in basalts, which are independent of absolute concentrations, immediately signify a common source ratio identical to the ratio in the basalts. However, a somewhat unsatisfactory aspect of this approach (pointed out by Sims and DePaolo [1997]) is that data arrays with zero slopes have zero correlation coefficients. In addition the variables used in such a plot are not independent of each other. Both effects make a statistical analysis of the significance of such results difficult or impossible. From this point of view, a plot of $\log \mathrm{C}_{1}$ versus $\log \mathrm{C}_{2}$ is superior [Jochum et al., 1983; Sims and DePaolo, 1997] because (1) it weights the data according to lognormal distribution and (2) it allows a meaningful statistical assessment of the correlation coefficient between the two elements. The relevance of lognormal distributions of trace elements in rocks was established long ago by Ahrens [1954]. Such loglog plots have also been used by cosmochemists for the purpose of comparative planetology for a long time [e.g., Wänke et al., 1974].

[24] Sims and DePaolo [1997] pointed out that the partial melting equation, written in logarithmic form,

$$
\log C_{B}^{l}=\log \left(\frac{m}{C_{A}^{l}}+b\right)^{-1}
$$

where

$$
m=\frac{C_{A}^{\text {source }}\left(1-D_{B}\right)}{C_{B}^{\text {source }}\left(1-D_{A}\right)}
$$


and

$$
b=\frac{\left(D_{B}-D_{A}\right)}{C_{B}^{\text {source }}\left(1-D_{A}\right)},
$$

takes on the simple, linear form

$$
\log C_{A}^{l}=\log C_{B}^{l}-\log m,
$$

where $m=\frac{C_{A}^{\text {source }}}{C_{B}^{\text {source }}}$ is the concentration ratio in the source, if the ${ }^{B}$ solid-liquid partition coefficients of the two elements concerned, $\mathrm{D}_{1}$ and $\mathrm{D}_{2}$, are identical.

[25] The case described above is strictly relevant only to a series of partial melts generated by variable degrees of equilibrium partial melting from sources of identical composition. As pointed out above, the main variation in the N-MORB - E-MORB suite described here actually lies in the sources, not in the degrees of partial melting. Although both we and Donnelly et al. also argue that the enriched source characteristics are ultimately generated by partial melting processes, it is quite likely that a significant portion of the overall chemical variation seen in these suites is caused by variable degrees of depletion. In other words, the depleted members of the E-MORB - N-MORB suite may be residues of variable degrees of melt removal. Because of this, we extend the linear relationship to include the depleted solid residues of partial melts:

Writing

$$
C_{A}^{l}=\frac{C_{A}^{s}}{D_{A}}, C_{B}^{l}=\frac{C_{B}^{s}}{D_{B}}
$$

equation (2) becomes

$$
\begin{gathered}
\log \frac{C_{A}^{\text {res }}}{D_{A}}=\log \frac{C_{B}^{\text {res }}}{D_{B}}-\log m \\
\log C_{A}^{\text {res }}-\log D_{A}=\log C_{B}^{\text {res }}-\log D_{B}-\log m .
\end{gathered}
$$

And if $D_{A}=D_{B}$, we obtain

$$
\log C_{A}^{r e s}=\log C_{B}^{r e s}-\log m .
$$

Equations (2) and (3) have exactly the same form so that, in log-log space, concentrations in melts and residues of two elements with identical partition coefficients follow the same linear relationship with a slope of 1.0.

[26] In the case of our N. Atlantic N-MORB to E-MORB suite, the absolute concentrations of highly incompatible elements vary by as much as a factor of 40. Such a variation cannot be ascribed only to local differences in the degree of melting, but must also, and primarily so, reflect differences in source concentrations. If these source differences were produced by melt depletion and/or enrichments with identical partition coefficients as those effective during the final melting process, then the concentration correlation plots of two elements with identical partition coefficients (in both the enriched and the depleted melts) will form a single linear array in log-log space, and its slope will be unity.

[27] If the partition coefficients of the two elements are not identical but both elements are moderately to highly incompatible, the log-log plots will not be strictly linear, but the deviations from linearity will be small enough so that real data arrays with only moderate scatter will appear to be linear with high correlation coefficients. When the slope of such a pseudo-linear array is greater than unity, the partition coefficient of the element plotted in the abscissa will be higher than that of the element plotted in the ordinate. Given these systematics, it becomes a simple procedure to test a given trace element against a series of others to determine which two elements have the most nearly identical partition coefficients: The slopes of a series of loglog correlations will change systematically from positive values through unity to negative values as the bulk partition coefficient of the element plotted in the ordinate changes from less than to greater than that of the element plotted in the abscissa.

[28] The relationships predicted from such simple depletion/enrichment and melting processes are indeed observed, both in the N. Atlantic and the CIR basalt suites. The results, obtained using the ProFit software package for two-error linear regressions, are summarized in Table 2. In Figure 11 we show actual regression plots (for the MAR suite only, for clarity) testing the slopes of $\log (\mathrm{Nb}, \mathrm{Ta}, \mathrm{K}$ and $\mathrm{Pb})$ against several other elements to determine relative compatibilities and to see which element is closest to the reference element in bulk partition coefficient. Figure 12 shows a summary of the slopes of all the log-log plots for both suites.

[29] In the MAR suite, the slopes for $\mathrm{Nb}$ (in the abscissa) decrease systematically from $\mathrm{Rb}$ (1.23), Th (1.014), Ta (0.995), U (0.96) to La (0.65). The corresponding sequence for the CIR suite is $\mathrm{Rb}$ (1.23), Ba (1.22), Th (1.03), U (0.92), Ta (0.90), La (0.59). Thus, in both cases, the correlations of $\log \mathrm{Nb}$ versus $\log \mathrm{Th}$ are highly 


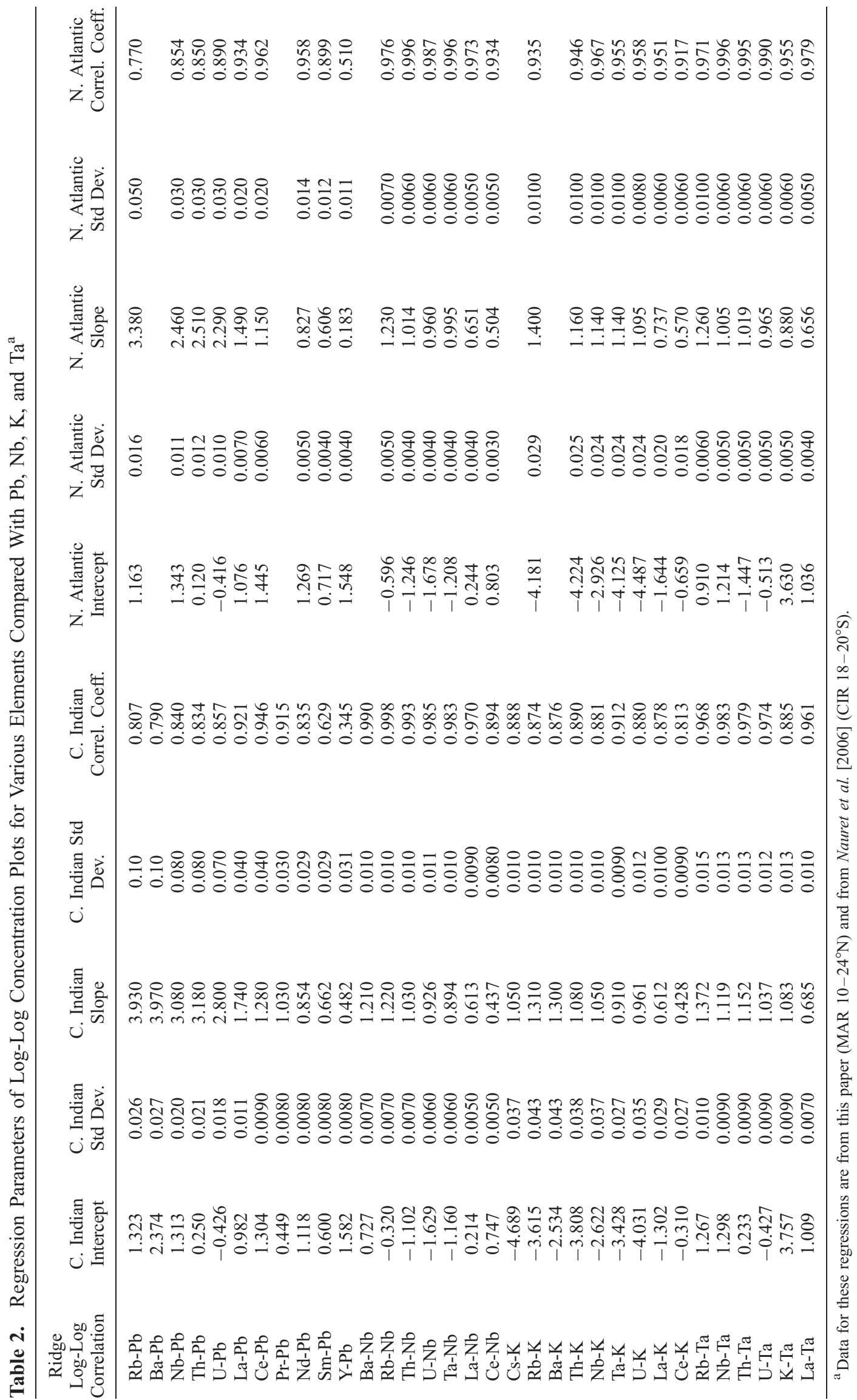



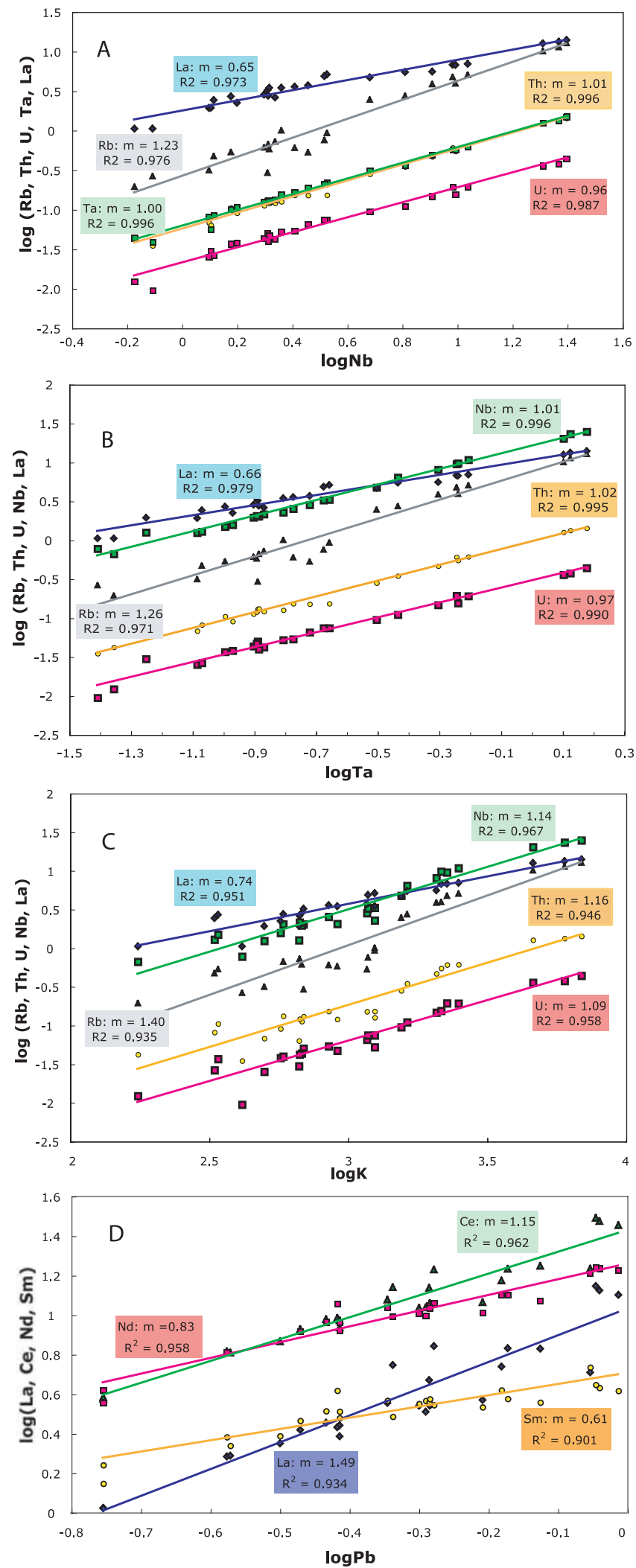

Figure 11. Examples of logarithmic concentration plots of (a) $\mathrm{Nb}$, (b) $\mathrm{Ta},(\mathrm{c}) \mathrm{K}$, and (d) Pb versus other elements of variable but generally similar incompatibility. Also shown are the slopes $(\mathrm{m})$ and correlation coefficients $\left(\mathrm{r}^{2}\right)$ for each element pair. Such correlations yield a slope of $\mathrm{m}=1.0$ for element pairs of identical bulk partition coefficients (or "compatibility"). 

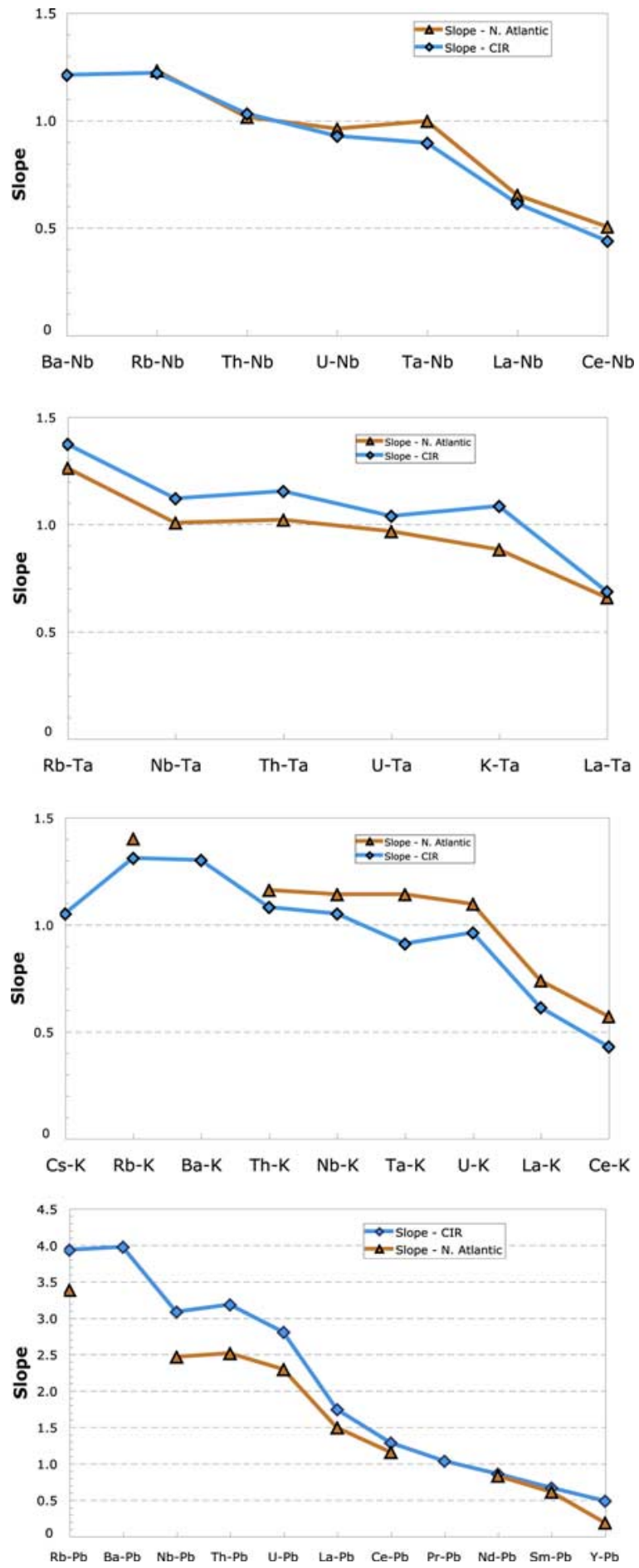

Figure 12. Complete set of slopes of the logarithmic concentration correlations for both regions (N. Atlantic and CIR), taken from Table 2. In general, the slopes decrease monotonically as the bulk partition coefficient of the element used in the ordinates of Figure 11 increases. This facilitates the identification of the element pair exhibiting a slope closest to $\mathrm{m}=1.0$. CIR data are from Nauret et al. [2006]. linear, with slopes very close to 1.0 and correlation coefficients of 0.995 and 0.996 , respectively. These results are in excellent agreement with those for seamounts located near the EPR [Niu and Batiza, 1997]. However, they differ from those for Iceland [Hofmann, 2003], where the $\mathrm{Nb}$ partition coefficient is significantly greater than the coefficient for Th, and lies between those of $\mathrm{U}$ and La.

[30] Except for $\mathrm{Ta}$, which shows significantly different behavior in the N. Atlantic and the CIR suites (see below), and $\mathrm{Ba}$, which has been omitted in the N. Atlantic suite (because of insufficient data), the sequences and the slopes of the correlation plots are remarkably similar. The shift in Ta compatibility causes the $\mathrm{Ta}-\mathrm{Nb}$ plots to have significantly different slopes in the two suites (Figure 12). In the MAR region, Ta is very similar to $\mathrm{Nb}$ (and $\mathrm{Th}$ ) with a $\log \mathrm{Nb}-\log \mathrm{Ta}$ slope of 1.01 (and a very high correlation coefficient of $\mathrm{r}=0.996$ ). In the CIR suite, the Nb-Ta correlation yields a significantly higher slope of 1.09 $(\mathrm{r}=0.982)$. Here, Ta is very similar to $\mathrm{U}$, with a slope of $1.01(\mathrm{r}=0.987)$. This is also the case for the Pacific seamounts [Niu and Batiza, 1997]. Future evaluations should show whether the shift of Ta compatibility from a position close to Th to one close to $U$ can be tied to more specific source fractionation processes.

[31] Another element ratio of considerable geochemical and geophysical interest is that of potassium to uranium. Jochum et al. [1983] found an average $\mathrm{K} / \mathrm{U}$ ratio of 12700 for both MORB and OIB on the basis of a rather small number of basalt analyses. This value has been widely used in the literature in spite of its limited database. Recently, Lassiter [2004] reviewed a much more current and extensive set of OIB data and concluded that $\mathrm{K} / \mathrm{U}$ ratios vary between about 15000 and 6000 and are negatively correlated with ${ }^{206} \mathrm{~Pb} /{ }^{204} \mathrm{~Pb}$. He did not, however, reassess the $\mathrm{K} / \mathrm{U}$ ratios of MORB. An overall assessment of the current database for MORB is difficult because of widely varying quality of data and freshness of samples. Here we consider two questions: (1) Do K/U ratios vary between N-MORB and E-MORB, and (2) which refractory lithophile element is most similar to potassium with regard to its bulk partition coefficient in two ocean ridge regions. Figure 5 shows that in the $\mathrm{N}$. Atlantic region, the $\mathrm{K} / \mathrm{U}$ ratio averages $15500 \pm 3100$ with no significant differences between enriched and depleted regions. In the CIR region, the average ratio is similar, $\mathrm{K} / \mathrm{U}=14650 \pm 3950$ [Nauret et al., 2006]. 
[32] Testing the slopes of $\log \mathrm{K}$ versus a series of other elements is shown in Figure 12. In the MAR suite, $\mathrm{K}$ is somewhat more compatible than $\mathrm{U}$ $(\mathrm{m}=1.09 ; \mathrm{r}=0.958)$ but significantly more incompatible than $\mathrm{La}(\mathrm{m}=0.74 ; \mathrm{r}=0.951)$. In the CIR suite, $\mathrm{K}$ compatibility is between $\mathrm{U}(\mathrm{m}=0.96 ; \mathrm{r}=0.88)$ and $\mathrm{Nb}(\mathrm{m}=1.05 ; \mathrm{r}=0.88)$. Thus there are subtle regional differences, but in both regions the results are remarkably close to those of Jochum et al. [1983], in that potassium partitioning is very close to that of uranium.

[33] Sims and DePaolo pointed out that the MORB data given by Hofmann et al. [1986], taken by themselves, would indicate a considerably higher bulk partition coefficient for lead than $\mathrm{Ce}$. In addition, they showed that $\mathrm{Ce} / \mathrm{Pb}$ ratios of those MORB data correlated negatively with small but significant $\mathrm{Eu}$ anomalies, an observation that had been missed in the original paper by Hofmann et al. This raises the possibility that $\mathrm{Ce} / \mathrm{Pb}$ ratios may be affected by plagioclase fractionation. In addition Rehkämper and Hofmann [1997] argued that, at least in the MORB environment, the bulk partition coefficient of $\mathrm{Pb}$ is closer to $\mathrm{Nd}$ than to $\mathrm{Ce}$. In view of these uncertainties and criticisms, a reevaluation of the compatibility of $\mathrm{Pb}$ relative to the REE is particularly important.

[34] Testing the slopes of log-log plots of lead versus $\mathrm{La}, \mathrm{Ce}, \mathrm{Nd}$, and $\mathrm{Sm}$ in the $\mathrm{N}$. Atlantic suite, we obtain values of $1.49,1.15,0.82$, and 0.61 for the slopes and $0.93,0.96,0.96$, and 0.90 for the correlation coefficients, respectively (Figure 12). It is clear that a slope of 1.0 would lie somewhere between the elements $\mathrm{Ce}$ and $\mathrm{Nd}$, so that plot of $\log \mathrm{Pr}$ versus $\log \mathrm{Pb}$ should have a slope very close to unity with a correlation coefficient of 0.96 or greater. Unfortunately since these REE data were obtained by isotope dilution, which cannot be used for the mono-isotopic Pr, we do not have data for Pr.

[35] The analogous exercise of the CIR suite yields slopes of $1.83(\mathrm{La}-\mathrm{Pb}), 1.27$ (Ce-Pb), $0.96(\mathrm{Pr}-\mathrm{Pb})$ and $0.73(\mathrm{Nd}-\mathrm{Pb})$. It is clear that in both suites the effective bulk partition coefficient of lead is closest to that of Pr. A new analysis of the global compatibility systematics of lead is beyond the scope of this paper, but at least in our two specific nearridge environments, lead and praseodymium have essentially identical bulk partition coefficients. This result, though not identical, is remarkably close to the conclusions reached twenty years ago by Hofmann et al. [1986], which placed $\mathrm{Pb}$ close to Ce on the basis of a global, but extremely limited set of data. It does not bear out the conclusion of Sims and DePaolo [1997] to the effect that lead has a much higher partition coefficient than Ce. Our analysis does not address the question of what causes the bulk partition coefficient of lead to be as high as $\operatorname{Pr}$ or Ce. However, the suggestion originally made by Hofmann [1988], namely that a residual sulfide phase is implicated has recently been more quantitatively evaluated by Hart and Gaetani [2006].

\subsection{Effect of Subduction-Related Alteration on the Recycled Material}

[36] In presenting our model for the origin of the enriched MORB source by recycling of oceanic alkali basalts, we started with the assumption that this material is not significantly modified by subduction-related processes affecting watersoluble, and therefore "mobile," elements. We now proceed with the assumption that such processes would be highly variable in nature, because they would depend (at least to a significant extent) on the specific degree of pre-subduction alteration and hydration of the oceanic crust, which is highly variable and depends strongly on oceanfloor tectonics. This means that the elements subject to such alteration (e.g., $\mathrm{K}, \mathrm{Rb}$ and $\mathrm{U}$ ) should show greater variations in abundances than the more "immobile" elements such as $\mathrm{Th}, \mathrm{Nb}$, $\mathrm{Ta}$, and the REE. However, variability of element abundances is caused not only by alteration effects but also by variations in source depletion and degree of melting. The latter effect has led to an alternative method of assessing relative compatibilities of trace elements. We will therefore assess the relative variabilities of the trace elements in order to see whether these are dominated by alteration effects or by enrichments and depletions caused by simple melting processes. If the observed variabilities can be accounted for by processes related to partial melting, we will conclude that alteration effects are relatively insignificant and can be neglected for the purposes of this paper.

[37] The method of assessing relative compatibilities of trace elements by their relative variabilities was introduced qualitatively by Hofmann [1988], and it was quantitatively elaborated by Schiano et al. [1993] and Dupré et al. [1994]. It is based on the observation that bulk partition coefficients are inversely related to variability in both, partial melts and their residues, in response to different degrees of partial melting. Figure 13 compares trace ele- 


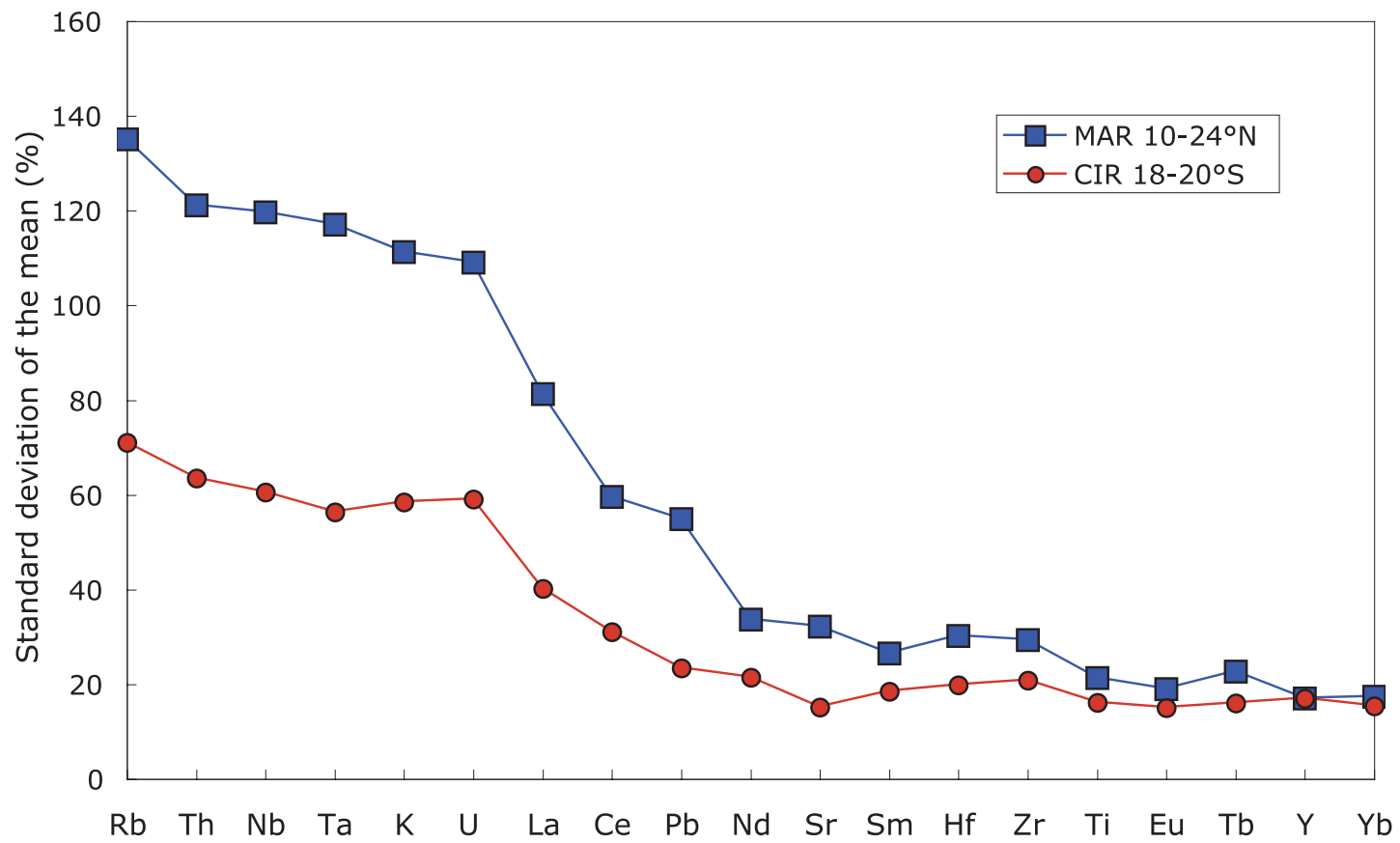

Figure 13. Variabilities (defined as percent standard deviation of the mean) of both sets of samples (CIR and MAR). Variabilities tend to decrease monotonically as the compatibility increases. CIR data are from Nauret et al. [2006].

ment variabilities (expressed as percent standard deviation of each population) in the two suites. It shows the expected systematic decrease from $\mathrm{Rb}$ to $\mathrm{Yb}$. This analysis shows that the variabilities of relatively "mobile" elements potassium and uranium are similar to those of similarly incompatible, but more immobile elements $\mathrm{Th}, \mathrm{Nb}$, and Ta. This provides circumstantial but nevertheless strong evidence that subduction-related alteration processes did not greatly affect the abundances of these elements, and it justifies our approach of neglecting such effects in our model for the origin of the enrichments. Slight differences in the relative magnitudes of these variabilities in the two regions may not be statistically significant, or they may reflect the regional differences in relative bulk partition coefficients discussed above. This does not rule out minor effects caused by alteration or subduction-related mobilization, but it limits their possible overall role in the major differentiation processes generating the E-MORBs investigated here. The question then arises why evidence for recycled altered material is so scarce, or possibly absent. The answer may lie in the fact that altered material is also wet, and it will therefore melt at rather low temperatures, and because of this, it might be reextracted by subduction-related magmatism and thus be kept from entering the deeper mantle. Certainly, additional work on N-MORB - E-MORB associations will be needed to evaluate whether these relationships hold in all MORB settings.

\section{Conclusions}

[38] 1. The MAR between 10 and $24^{\circ} \mathrm{N}$ contains a segment at $14^{\circ}-15^{\circ} \mathrm{N}$ with E-MORB which are enriched up to 40 times in highly incompatible elements over the depleted N-MORB to the north and the south of this zone. The enrichment correlates with radiogenic isotope enrichments indicating that it is primarily a property of the sources.

[39] 2. The enrichment is not related to any obvious mantle plume. It is very similar to the E-MORB in the MARK area recently described by Donnelly et al. [2004], and it can be explained by (recycled) metasomatic enrichments as proposed by these authors. However, it can be equally well explained by recycling of alkali basalts that are common on oceanic seamounts and islands.

[40] 3. We use the trace element variations in the $10-24^{\circ} \mathrm{N}$ MAR region and in the $18-20^{\circ} \mathrm{S}$ CIR 
segment [Nauret et al., 2006] to reassess the bulk partition coefficients of $\mathrm{Nb}, \mathrm{Ta}, \mathrm{K}$ and $\mathrm{Pb}$ relative to other trace elements. In both regions, $\mathrm{Nb}$ partitioning is similar to $\mathrm{Th}$, and $\mathrm{Pb}$ similar to $\mathrm{Pr}$. Tantalum partitioning is similar to $\mathrm{Nb}$ in the MAR region but closer to $K$ and $U$ in the CIR region. Potassium partitioning is similar to $U$ in the MAR suite, but is more incompatible in the CIR suite. These (relatively minor) differences are related primarily to the processes (enrichment and depletion) affecting the sources rather than the recent melting processes that produced these basalts.

\section{Acknowledgments}

[41] C.H. thanks Claire Bollinger for her help during the laboratory work and Henri Bougault for the financial support of IFREMER during part of this work. We thank Henri Bougault and Laure Dosso for providing the samples previously analyzed by them for isotopes and trace elements. Charlie Langmuir and Ken Sims provided in-depth reviews, which we found extremely helpful for clarifying several aspects of the paper. Ken Sims saved us from misrepresenting part of his paper, and Charlie Langmuir raised the issue of the short recycling time required, and he pointed out how the geographic restriction to the $14-15^{\circ}$ region sharpens up the quality of the mantle isochrons enormously, which persuaded us to include the isochron diagram in the paper. A.W.H. is grateful for the hospitality of the Institut de Physique du Globe de Paris. C.H. is thankful to Jérôme Dyment, who provided the bathymetric map. This is the IUEM contribution 1012.

\section{References}

Ahrens, L. H. (1954), The lognormal distribution of the elements (a fundamental law of geochemistry and its subsidiary), Geochim. Cosmochim. Acta, 5, 49-73.

Albarède, F. (2001), Radiogenic ingrowth in systems with multiple reservoirs: Applications to the differentiation of the mantle-crust system, Earth Planet. Sci. Lett., 189, 59-73.

Allègre, C. J. (1969), Comportement des systèmes U-Th-Pb dans le manteau supérieur et modèle d'évolution de ce dernier au cours des temps géologiques, Earth Planet. Sci. Lett., 5, 261-269.

Batiza, R. (1982), Abundances, distribution and sizes of volcanoes in the Pacific Ocean and implications for the origin of non-hotspot volcanoes, Earth Planet. Sci. Lett., 60, 195206.

Beattie, P. (1993), U-Th disequilibria and partitioning on melting of garnet peridotite, Nature, 363, 63-65.

Blundy, J. D., and B. J. Wood (1994), Prediction of crystalmelt partition coefficients from elastic moduli, Nature, 372, $452-454$.

Bougault, H., et al. (1988), Mantle heterogeneity from trace elements: MAR triple junction near $14^{\circ} \mathrm{N}$, Earth Planet. Sci. Lett., 88, 27-36.

Cheng, Q. C., K.-H. Park, J. D. Macdougall, A. Zindler, G. W. Lugmair, H. Staudigel, J. Hawkins, and P. Lonsdale (1987), Isotopic evidence for a hotspot origin of the Louisville Seamount Chain, in Seamounts, Islands, and Atolls, Geophys.
Monogr. Ser, vol. 43, edited by B. H. Keating et al., pp. 283-296, AGU, Washington, D. C.

Condomines, M., et al. (1987), Short-lived radioactive disequilibria and magma dynamics in Etna volcano, Nature, 325, 607-609.

Donnelly, K. E., et al. (2004), Origin of enriched ocean ridge basalts and implications for mantle dynamics, Earth Planet. Sci. Lett., 226, 347-366.

Dosso, L., et al. (1991), Sr-Nd-Pb geochemical morphology between $10^{\circ}$ and $17^{\circ} \mathrm{N}$ on the Mid-Atlantic Ridge: A new MORB isotope signature, Earth Planet. Sci. Lett., 106, 29-43.

Dosso, L., et al. (1993), Geochemical morphology of the north Mid-Atlantic Ridge, $10^{\circ}-24^{\circ} \mathrm{N}$ : Trace element-isotope complementarity, Earth Planet. Sci. Lett., 120, 443-462.

Dosso, L., et al. (1999), The age and distribution of mantle heterogeneity along the Mid-Atlantic Ridge $\left(31-41^{\circ} \mathrm{N}\right)$, Earth Planet. Sci. Lett., 170, 269-286.

Dupré, B., et al. (1994), Variability: A new parameter which emphasizes the limits of extended rare earth diagrams, Bull. Soc. Geol. Fr., 165, 3-13.

Eisele, J., et al. (2002), The role of sediment recycling in EM-1 inferred from $\mathrm{Os}, \mathrm{Pb}, \mathrm{Hf}, \mathrm{Nd}, \mathrm{Sr}$ isotope and trace element systematics of the Pitcairn hotspot, Earth Planet. Sci. Lett., 196, 197-212.

Etoubleau, J., P. Cambon, H. Bougault, and J. L. Joron (1991), Analyse précise du niobium dans les échantillons géologiques, in RX GAMS 91: Les Rayons et Leurs Applications, 17-19 Septembre 1991 - Blois, Actes du Congrès, pp. 181186, Groupe pour l'Avancement des Sci. Anal., Paris.

Hanson, G. N. (1980), Rare earth elements in petrogenetic studies of igneous systems, Annu. Rev. Earth Planet. Sci., 8, 371-406.

Hart, S. R., and T. Dunn (1993), Experimental CPX/melt partitioning of 24 elements, Contrib. Mineral. Petrol., 113, $1-8$.

Hart, S. R., and G. A. Gaetani (2006), Mantle lead paradoxes: The sulfide solution, Contrib. Mineral. Petrol., 152, 295308, doi:10.1007/s00410-006-0108-1.

Hawkins, J. W. J., et al. (1987), Petrologic evolution of the Louisville seamount chain, in Seamounts, Islands, and Atolls, Geophys. Monogr. Ser., vol. 43, edited by B. H. Keating et al., pp. 235-254, AGU, Washington, D. C.

Hofmann, A. W. (1988), Chemical differentiation of the Earth: the relationship between mantle, continental crust, and oceanic crust, Earth Planet. Sci. Lett., 90, 297-314.

Hofmann, A. W. (1989), A unified model for mantle plume sources, Eos Trans. AGU, 70, 503.

Hofmann, A. W. (2003), Sampling mantle heterogeneity through oceanic basalts: Isotopes and trace elements, in The Mantle and Core, vol. 2, edited by R. W. Carlson, pp. 61-101, Elsevier, New York.

Hofmann, A. W., and M. D. Feigenson (1983), Case studies on the origin of basalt. I. Theory and reassessment of Grenada basalts, Contrib. Mineral. Petrol., 84, 382-389.

Hofmann, A. W., and W. M. White (1982), Mantle plumes from ancient oceanic crust, Earth Planet. Sci. Lett., 57, $421-436$.

Hofmann, A. W., et al. (1986), Nb and $\mathrm{Pb}$ in oceanic basalts: New constraints on mantle evolution, Earth Planet. Sci. Lett., 79, 33-45.

Janney, P. E., et al. (2000), Geochemical evidence from the Pukapuka volcanic ridge system for a shallow enriched mantle domain beneath the South Pacific Superswell, Earth Planet. Sci. Lett., 181, 47-60.

Jochum, K.-P., et al. (1983), K, U, and Th in mid-ocean ridge basalt glasses and heat production, $\mathrm{K} / \mathrm{U}$, and $\mathrm{K} / \mathrm{Rb}$ in the mantle, Nature, 306, 431-436. 
Johnson, K. T. M. (1994), Experimental cpx/and garnet/melt partitioning of REE and other trace elements at high pressure: petrogenetic implications, Min. Mag., 58A, 454-455.

Kelemen, P. B., et al. (1993), Relative depletion of niobium in some arc magmas and the continental crust: Partitioning of $\mathrm{K}, \mathrm{Nb}, \mathrm{La}$ and $\mathrm{Ce}$ during melt/rock reaction in the upper mantle, Earth Planet. Sci. Lett., 120, 111-134.

Kennedy, A. K., et al. (1993), An experimental study of trace element partitioning between olivine, orthopyroxene and melt in chondrules-Equilibrium value and kinetic effects, Earth Planet. Sci. Lett., 115, 177-195.

Klein, E. M., and C. H. Langmuir (1987), Global correlations of ocean ridge basalt chemistry with axial depth and crustal thickness, J. Geophys. Res., 92, 8089-8115.

Kokfelt, T. F., et al. (2003), Upwelling and melting of the Iceland plume from radial variation of ${ }^{238} \mathrm{U}_{-}^{230} \mathrm{Th}$ disequilibria in postglacial volcanic rocks, Earth Planet. Sci. Lett., $214,167-186$.

Lassiter, J. C. (2004), Role of recycled oceanic crust in the potassium and argon budget of the Earth: Toward a resolution of the "missing argon" problem, Geochem. Geophys. Geosyst., 5, Q11012, doi:10.1029/2004GC000711.

Manhès, G., et al. (1984), U-Th-Pb systematics of the eucrite "Juvinas": Precise age determination and evidence for exotic lead, Geochim. Cosmochim. Acta, 48, 2247-2264.

Mata, J., et al. (1998), Elemental and isotopic ( $\mathrm{Sr}, \mathrm{Nd}$ and $\mathrm{Pb}$ ) characteristics of Madeira island basalts: Evidence for composite HIMU-EM I plume fertilizing lithosphere, Can. J. Earth Sci., 35, 980-997.

McDonough, W. F., and S.-S. Sun (1995), The composition of the Earth, Chem. Geol., 120, 223-253.

McKenzie, D., et al. (2004), Source enrichment processes responsible for isotopic anomalies in oceanic island basalts, Geochim. Cosmochim. Acta, 68, 2699-2724.

Minster, J.-F., and C. J. Allègre (1978), Systematic use of trace elements in igneous processes. Part III: Inverse problem of batch partial melting in volcanic suites, Contrib. Mineral. Petrol., 68, 37-52.

Nauret, F., et al. (2006), Correlated trace element- $\mathrm{Pb}$ isotope enrichments in Indian MORB along $10^{\circ}-20^{\circ} \mathrm{S}$, Central Indian Ridge, Earth Planet. Sci. Lett., 245, 137-152.

Niu, Y., and R. Batiza (1997), Trace element evidence from seamounts for recycled oceanic crust in the Eastern Pacific mantle, Earth Planet. Sci. Lett., 148, 471-483.

Niu, Y., et al. (2002), Geochemistry of near-EPR seamounts: Importance of source vs. process and the origin of enriched mantle component, Earth Planet. Sci. Lett., 199, 327-345.

Rehkämper, M., and A. W. Hofmann (1997), Recycled ocean crust and sediment in Indian Ocean MORB, Earth Planet. Sci. Lett., 147, 93-106.

Richard, P., et al. (1976), ${ }^{143} \mathrm{Nd} /{ }^{146} \mathrm{Nd}$ a natural tracer: An application to oceanic basalt, Earth Planet. Sci. Lett., 31, $269-278$.
Salters, V. J. M., and J. Longhi (1999), Trace element partitioning during the initial stages of melting beneath midocean ridges, Earth Planet. Sci. Lett., 166, 15-30.

Schiano, P., et al. (1993), Variability of trace elements in basaltic suites, Earth Planet. Sci. Lett., 119, 37-51.

Schilling, J.-G. (1973), Iceland mantle plume: geochemical evidence along Reykjanes Ridge, Nature, 242, 565-571.

Schilling, J.-G. (1975), Rare-earth variations across "normal segments" of the Reykjanes Ridge, $60^{\circ}-53^{\circ} \mathrm{N}$, Mid-Atlantic Ridge, $29^{\circ} \mathrm{S}$ and East Pacific Rise, $2^{\circ}-19^{\circ} \mathrm{S}$, and evidence on the composition of the underlying low-velocity layer, J. Geophys. Res., 80, 1459-1473.

Schilling, J.-G., et al. (1985), Hotspot-migrating ridge interaction in the South Atlantic, Nature, 313, 187-191.

Sims, K. W. W., and D. J. DePaolo (1997), Inferences about mantle magma sources from incompatible element concentration ratios in oceanic basalts, Geochim. Cosmochim. Acta, $61,765-784$.

Smith, W. H. F., and D. T. Sandwell (1994), Bathymetric prediction from dense satellite altimetry and sparse shipboard bathymetry, J. Geophys. Res., 99, 21,803-21,824.

Smith, W. H. F., and D. T. Sandwell (1997), Global sea floor topography from satellite altimetry and ship depth soundings, Science, 277, 1956-1962.

Stracke, A., M. Bizimis, and V. J. M. Salters (2003), Recycling oceanic crust: Quantitative constraints, Geochem. Geophys. Geosyst., 4(3), 8003, doi:10.1029/2001GC000223.

Sun, S.-S., and W. F. McDonough (1989), Chemical and isotope systematics of oceanic basalts: Implications for mantle composition and processes, in Magmatism in the Ocean Basins, edited by A. D. Saunders and M. J. Norry, Geol. Soc. Spec. Publ., 42, 313-345.

Sun, S.-S., et al. (1979), Geochemical characteristics of midocean ridge basalts, Earth Planet. Sci. Lett., 44, 119-138.

Turner, S. P., et al. (1997), U-Th isotope disequilibria and ocean island basalts generation in the Azores, Chem. Geol., $139,145-164$.

Wänke, H., et al. (1974), Chemistry of Apollo 16 and 17 samples: Bulk composition, late stage accumulation and early differentiation of the Moon, Proc. Lunar Sci. Conf. 5th, 1307-1335.

White, W. M., et al. (1993), Petrology and geochemistry of the Galapagos Islands: Portrait of a pathological mantle plume, J. Geophys. Res., 98, 19,533-19,563.

Wood, B. J., and J. D. Blundy (1997), A predictive model for rare earth element partitioning between clinopyroxene and anhydrous silicate melt, Contrib. Mineral. Petrol., 129, $166-181$.

Workman, R. K., S. R. Hart, M. Jackson, M. Regelous, K. A. Farley, J. Blusztajn, M. Kurz, and H. Staudigel (2004), Recycled metasomatized lithosphere as the origin of the Enriched Mantle II (EM2) end-member: Evidence from the Samoan Volcanic Chain, Geochem. Geophys. Geosyst., 5, Q04008, doi:10.1029/2003GC000623. 